\title{
Intraspecific variation of phragmocone chamber volumes throughout ontogeny in the modern nautilid Nautilus and the Jurassic ammonite Normannites
}

Amane Tajika, Naoki Morimoto, Ryoji Wani, Carole Naglik, Christian Klug

Nautilus remains of great interest to palaeontologists after a long history of actualistic comparisons and speculations on aspects of the palaeoecology of fossil cephalopods, which are otherwise impossible to assess. Although a large amount of work has been dedicated to Nautilus ecology, conch geometry and volumes of shell parts and chambers have been studied less frequently. In addition, although the focus on volumetric analyses for ammonites has been increasing recently with the development of computed tomographic technology, the intraspecific variation of volumetric parameters has never been examined. To investigate the intraspecific variation of the phragmocone chamber volumes throughout ontogeny, 30 specimens of Recent Nautilus pompilius and two Middle Jurassic ammonites (Normannites mitis) were reconstructed using computed tomography and grinding tomography, respectively. Both of the ontogenetic growth trajectories from the two Normannites demonstrate logistic increase. However, a considerable difference in Normannites has been observed between their entire phragmocone volumes (cumulative chamber volumes), in spite of their similar morphology and size. Ontogenetic growth trajectories from Nautilus also show a high variation. Sexual dimorphism appears to contribute significantly to this variation. Finally, covariation between chamber widths and volumes was examined. The results illustrate the strategic difference in chamber construction between Nautilus and Normannites. The former genus persists to construct a certain conch shape, whereas the conch of the latter genus can change its shape flexibly under some constraints. 


\section{Intraspecific variation of phragmocone chamber volumes}

\section{2 throughout ontogeny in the modern nautilid Nautilus and the}

\section{Jurassic ammonite Normannites}

5 Amane Tajika ${ }^{1}$, Naoki Morimoto ${ }^{2}$, Ryoji Wani ${ }^{3}$, Carole, Naglik ${ }^{1}$ and Christian Klug ${ }^{1}$

6 1Paläontologisches Institut und Museum, Universität Zürich, Karl Schmid-Strasse 4, CH-8006

7 Zürich, Switzerland

8 22 Laboratory of Physical Anthropology, Graduate School of Science, Kyoto University,

9 Kitashirakawa Oiwake-cho, Sakyo-ku 606-8502 Kyoto, Japan

$10{ }^{3}$ Faculty of Environment and Information Sciences, Yokohama National University, Yokohama, 11 240-8501, Japan

\section{ABSTRACT}

Nautilus remains of great interest to palaeontologists after a long history of actualistic comparisons and speculations on aspects of the palaeoecology of fossil cephalopods, which are otherwise impossible to assess. Although a large amount of work has been dedicated to Nautilus ecology, conch geometry and volumes of shell parts and chambers have been studied less frequently. In addition, although the focus on volumetric analyses for ammonites has been increasing recently with the development of computed tomographic technology, the intraspecific variation of volumetric parameters has never been examined. To investigate the intraspecific 
21 variation of the phragmocone chamber volumes throughout ontogeny, 30 specimens of Recent

22 Nautilus pompilius and two Middle Jurassic ammonites (Normannites mitis) were reconstructed

23 using computed tomography and grinding tomography, respectively. Both of the ontogenetic

24 growth trajectories from the two Normannites demonstrate logistic increase. However, a

25 considerable difference in Normannites has been observed between their entire phragmocone

26 volumes (cumulative chamber volumes), in spite of their similar morphology and size.

27 Ontogenetic growth trajectories from Nautilus also show a high variation. Sexual dimorphism

28 appears to contribute significantly to this variation. Finally, covariation between chamber widths

29 and volumes was examined. The results illustrate the strategic difference in chamber construction between Nautilus and Normannites. The former genus persists to construct a certain

31 conch shape, whereas the conch of the latter genus can change its shape flexibly under some 32 constraints. 


\section{INTRODUCTION}

Ammonoids and nautiloids are well-known, long-lived molluscan groups, both of which faced devastation at the end of the Cretaceous, but with different responses: extinction versus survival. What these two groups have in common is the external conch, which makes them superficially similar. Because of that, a number of palaeontologists investigated the ecology and anatomy of living Nautilus as an analogy for those of extinct ammonites over the last decades (e.g., Collins et al., 1980; Saunders \& Landman, 1987; Ward, 1987; 1988). However, it was Jacobs \& Landman (1993) who argued that, despite its superficial morphologic similarity, Nautilus was an insufficient model to reconstruct ammonoid palaeoecology, given their phylogenetic positions, which are distant within the Cephalopoda. This argument is now widely accepted (e.g., Warnke $\&$ Keupp, 2005). Whereas palaeoecology and evolution of ammonoids need to be discussed based on their own fossil record, those of modern Nautilus can be satisfactorily analogized to fossil nautilids, which have borne persistent conch morphologies throughout their evolution (Ward, 1980).

Molluscan conchs are not only exoskeletal structures but also retain a complete record of their ontogeny because of their accretionary growth. One of the most important apomorphic structures of cephalopods, the chambered part of their conch (phragmocone), was used by most cephalopods and is still used by some cephalopods as a buoyancy device. The ammonite phragmocone has been of great interest for palaeontologists, in order to reveal otherwise-obscure aspects of ammonite palaeoecology (Geochemical analyses: Moriya et al., 2003; Lukeneder et al., 2010; Stevens et al., 2015; 2 dimensional analyses of septal angles: Kraft et al., 2008; Arai \& Wani, 2012). Buoyancy had not been examined by quantifying phragmocone volumes due to the lack of adequate methods until modern scanning technique enabled to reconstruct complete 
ammonite empirical volume models (Lemanis et al., 2015; Naglik et al., 2015a; Tajika et al., 2015). Unfortunately, all of these contributions included only one specimen per species due to the great expenditure of time needed for segmenting the image stacks. Conclusions from such limited studies may be biased if the examined specimens represent more or less extreme variants of one species (intraspecific variation). The life mode of living Nautilus is known to be essentially demersal, retaining their buoyancy as either roughly neutral when active or slightly negative when at rest (Ward \& Martin, 1978), even though they change their habitat frequently via vertical migration (Dunstan et al., 2011). The majority of Nautilus ecology research has included studies on anatomy, behaviour, and habitat, whereas geometry and volume of their phragmocones, which are similar to that of fossil nautiloids, have been examined less frequently (e.g., Ward, 1979; Hoffmann \& Zachow, 2011). Investigation of the relationship between Nautilus conchs and their ecology could become a reference to examine the relationship between fossil cephalopods and their palaeoecology.

$$
\text { Multiple methods have been applied to reconstruct conchs of cephalopods including both }
$$
fossilized and extant animals (Kruta et al., 2011; Hoffmann et al., 2014; Lemanis et al., 2015; Naglik et al., 2015b; Tajika et al., 2015; for general aspects of virtual palaeontology, see Garwood et al., 2010; Sutton et al., 2014). Non-destructive computed tomography (CT) superficially appears to be the best suitable method because rare fossils can be analysed without destroying them. Medical scanners are often used, but they often yield insufficient contrast between conch and internal sediment or cement because these materials may have similar densities (e.g., Garwood et al., 2010; Hoffmann \& Zachow, 2011). Furthermore, the resolution obtained from medical scanners is not adequate, specifically in such cases where accurate measurements of minute structures such as ammonite protoconchs (as small as $0.5 \mathrm{~mm}$ in 
diameter; e.g., Lemanis et al., 2015) are required. Fossil cephalopods are thus difficult materials to examine by this non-destructive method, but conchs of living cephalopods with no sediment filling can easily be reconstructed with a good resolution. Computed microtomography $(\mu \mathrm{CT})$ is an alternative because it has a stronger beam, resulting in high resolution and thus better reconstructions. $\mu \mathrm{CT}$-imagery produced using high energy levels has greater penetrative power but suffers from the lack of contrast, however, making the subsequent segmentation process difficult.

By contrast, Lemanis et al. (2015) presented the first successful attempt to reconstruct an ammonite ammonitella in detail. They scanned a perfectly preserved hollow ammonite using phase contrast tomography. Propagation phase contrast X-ray synchrotron microtomography (PPCSR- $\mu \mathrm{CT}$ ) was employed by Kruta et al. (2011) who reconstructed ammonite radulae in detail. The limited availability of the facility, heavy data load, and potential contrast problems discourage application of this method for fossil cephalopods. In contrast to the non-destructive methods, destructive grinding tomography can be used to reconstruct fossilized cephalopods (Naglik et al., 2015b; Tajika et al., 2015). This method, which preserves colour information of the shells (aiding in segmentation), does not require hollow preservation of fossils, thus permitting the examination of all well-preserved fossils without suffering from noise such as beam hardening or poor contrast, which commonly occur when using CT.

Volumetric analyses of intraspecific variability of phragmocone chambers throughout ontogeny have not previously been analysed in either Nautilus or ammonoids. Such data may contribute to the better understanding of the palaeoecology of extinct ammonoids and nautiloids. The aims of this study are to answer the following questions based on empirical 3D models reconstructed from real specimens: (1) How did chamber volumes change through ontogenetic 
104 development of ammonites and nautilids? (2) How much did the volumetric growth trajectories

105 differ between two conspecific ammonites (exemplified using middle Jurassic Normannites)? (3)

106 What was the intraspecific variation of volumetric growth trajectories of modern Nautilus? (4)

107 Are the differences in chamber volumes between male and female nautilids significant? (5) Is

108 there a difference in construction of chambers between the ammonites and modern Nautilus?

\section{MATERIAL}

111 Two ammonite specimens examined are from the Middle Jurassic and belong to the genus

112 Normannites (Normannites mitis). One of them (Nm. 1) was reconstructed by Tajika et al.

113 (2015) to test its buoyancy. Both specimens were found in the Middle Bajocian (Middle Jurassic)

114 of Thürnen, Switzerland. The nicely preserved specimens are suitable for 3D reconstruction,

115 even though one of the specimens (Nm. 2) has an incomplete aperture, which does not allow for

116 buoyancy calculation. The maximum conch diameters of Nm. 1 and Nm. 2 are $50.0 \mathrm{~mm}$ and 49.0

$117 \mathrm{~mm}$, respectively.

118 An additional 30 conchs of Recent Nautilus pompilius (21 adults: 12 males, 9 females; 9

119 juveniles) were also studied. All of the conchs were collected in the Tagnan area in the

120 Philippines (see fig. 1 in Wani, 2004; fig. 1 in Yomogida \& Wani, 2013). Maturity of Nautiilus

121 was defined as bearing black band, or septal crowding (for mature modification of Nautilus see

122 Klug, 2004). Males and females were differentiated based on previous studies: mature males

123 have larger shells and a broader, rounder aperture than females (Stenzel, 1964; Haven, 1977;

124 Saunders \& Spinosa, 1978; Arnold, 1984). In the juvenile stage, however, the sex is

125 indeterminable since the morphological differences of shells are not profound. The details of the 
126 specimens are summarized in Table 1. The specimens are stored in Mikasa City Museum, 127 Hokkaido, Japan.

128

129

METHODS

130

3D reconstructions of ammonites

131 Grinding tomography was employed to reconstruct the two Jurassic ammonite specimens. This

132 method has been applied to previous studies for invertebrates, e.g., bivalves (Götz, 2003; 2007;

133 Götz \& Stinnesbeck, 2003; Hennhöfer et al., 2012, Pascual-Cebrian et al., 2013) and

134 ammonoids (Naglik et al., 2015b: Tajika et al., 2015). During each of the 422 grinding phases,

$1350.06 \mathrm{~mm}$ was automatically ground off of the specimens until the specimen was completely

136 destroyed. Subsequently, each ground surface was automatically scanned with a resolution of

1372400 dpi. Due to the very high number of slices and the very time consuming segmenting

138 process, only every fourth scan of the obtained image stack were segmented. The voxel sizes of x,

$139 \mathrm{y}$ and $\mathrm{z}$ dimensions are $0.025,0.025$ and $0.24 \mathrm{~mm}$, respectively. We separately segmented the

140 external conch, all septa, and the siphuncle manually using Adobe ${ }^{\circledR}$ Illustrator (Adobe Systems).

141 The segmented image stacks have been exported to VGstudiomax ${ }^{\circledR} 2.1$ (Volume Graphics),

142 which produced 3D models out of the 2D image stacks. Further technical details for the

143 ammonite reconstructions are given in Tajika et al. (2015) and for the general procedure of

144 grinding tomography in Pascual-Cebrian et al. (2013).

145

146

3D reconstructions of modern Nautilus 
147 Conchs of all specimens were scanned at the Laboratory of Physical Anthropology of Kyoto

148 University using a 16-detector-array CT device (Toshiba Alexion TSX-032A) with the following

149 data acquisition and image reconstruction parameters: beam collimation: $1.0 \mathrm{~mm}$; pitch: 0.688 ;

150 image reconstruction kernel: sharp (FC30); slice increment: $0.2 \mathrm{~mm}$; tube voltage and current:

$151120 \mathrm{kV} 100 \mathrm{~mA}$. This resulted in volume data sets with isotropic spatial resolution in the range of

1520.311 and $0.440 \mathrm{~mm}$. The obtained data sets were exported to Avizo ${ }^{\circledR} 8.1$ (FEI Visualization

153 Sciences Group) where segmentation was conducted. As mentioned in Hoffmann et al. (2014),

154 the calculated mass of a specimen based on the CT data set does not correspond exactly to the

155 actual mass measured on the physical specimen due to noise and the partial volume effect (PVE)

156 from the scan, which may cause significant errors during the segmentation process. Wormanns et

157 al., (2004) reported that segmentation can also introduce errors between specimens. In our scans,

158 the resulting differences between the actual masses of the conchs and the calculated mass ranged

159 from 50 to $63 \%$. However, use of the same devices and methods and a combination of the same

160 grey-scale threshold value for the outer whorls and the manual tracing for the innermost whorls

161 reduce the noise and preserve the overall trend of variability in volumes between each specimen.

162 Out of 45 scanned specimens, only 30 scanned specimens with nearly the same contrast were

163 carefully chosen and analysed, while scans from other 15 specimens with different contrasts

164 were discarded to minimize errors which may occur from differences in contrast between scans.

165 Nevertheless, the variability is to some degree affected by the errors due to the noise and PVE. A

166 list of the differences between calculated shell volumes and estimated actual shell volumes

167 calculated from mass measurements is provided in Supplemental Table (the estimated volume

168 error: $60.8-91.3 \%)$. The segmented data sets were exported as STL files using the software

169 Avizo ${ }^{\circledR 8.1}$. The volumetric data from the phragmocone were extracted and calculated in 
170 Meshlab (ISTL-CNR research center) and Matlab 8.5 (Math Works), respectively. The

171 measurements of the diameters and widths of the conchs were conducted with the program

172 ForMATit developed by NM.

RESULTS

Difference between two Normannites specimens in ontogenetic volume changes

176

177

178

179

180

181

Constructed 3D models of the ammonites are shown in Fig. 1 (1A-1D). Measured chamber volumes (Table 2) were plotted against chamber numbers (Fig. 2). In the two Normannites specimens, the overall trends of growth trajectories of individual chamber volumes (Fig. 2A) are more or less the same, showing logistic increase throughout ontogeny until the onset of the socalled 'terminal countdown' (Seilacher \& Gunji, 1993) when they start showing a downward trend over the last 5 chambers (Nm. 1) and over the last 7 chambers (Nm. 2). The curve from Nm. 1 illustrates a nearly steady growth rate even though a syn vivo epizoan worm with mineralized tube grew on the fifth whorl of the ammonite (Tajika et al., 2015). By contrast, Nm. 2 does not show traces of any syn vivo epizoans, but it displays a sudden decrease of the volume of the 45th chamber where another trend sets off, which persists to the last chamber. In addition, we plotted the cumulative volumes of the phragmocone chambers against chamber numbers (Fig. 2B). Since the curves are derivatives of those of Fig. 2, the phragmocone volumes increase with the same trend. The cumulative phragmocone volume of Nm. 1 is larger than that of Nm. 2, although the latter retained the larger phragmocone volume throughout ontogeny until the onset of the morphologic countdown. 
192 Intraspecific variability of modern Nautilus in ontogenetic volume changes

193 Constructed 3D models of modern Nautilus are shown in Fig.1 (2A-2D). As in the Jurassic

194 ammonite, individual chamber volumes and phragmocone volumes (Table 3) were plotted

195 against chamber numbers (Fig. 3A; B). Fig. 3 shows that all the curves increase logistically, as in

196 the ammonites, with a rather high variability. As far as the terminal countdown is concerned,

197 only the last or no chamber of the adult specimens shows the volume decrease. By contrast, the

198 two ammonites show this decrease over the last 5 to 7 chambers (even higher numbers of

199 chambers may be included in other ammonite species: e.g., 18 in the Late Devonian Pernoceras,

20014 in the Early Carboniferous Ouaoufilalites; see Korn et al., 2010; Klug et al., 2015) bearing

201 the irregular growth. It has been reported that mature males of Nautilus from the Fiji Islands

202 have larger shells and a broader, rounder aperture than those of females (Stenzel, 1964; Haven,

203 1977; Saunders \& Spinosa, 1978; Arnold, 1984) but there were no significant differences

204 between sexes in shell form in Nautilus from the Philippines (Tanabe et al., 1983). In order to

205 assess the differences between male and female conchs, their growth trajectories are shown in

206 Fig. 4. Maximum diameters of the conchs versus number of chambers (Fig. 5A) and maximum

207 diameters versus phragmocone volumes are also plotted (Fig. 5B) to assess if previously-

208 recognized morphologic differences between males and females of Nautilus are detectable here.

209 A statistical test (analysis of the residual sum of squares; ARSS) was carried out to determine

210 whether there are differences between males and females in growth trajectories (Fig. 4B) and

211 morphological features (maximum diameters of conchs vs. number of chambers; maximum

212 diameters of conchs vs. phragmocone volumes; Fig. 5A; B). This test is used to compare linear

213 models (Zar, 1996). A similar statistical test, which compares non-linear models, described by

214 Akamine (2004) was also conducted for growth trajectories of males and females (Fig. 4C) to 
215 verify whether or not the results from ARSS are valid. The results of the statistical tests suggest

216 that there are significant differences between males and females (Tables 5, 6).

\section{Comparison of chamber formation between ammonites and Nautilus}

219 Widths (for Normannites: Table 2; for Nautilus: Table 4) and volumes of each chamber were plotted against chamber numbers for the ammonites (Fig. 6) and Nautilus (Fig. 7). It should be noted that the widths of each chamber for the ammonites may not be very accurate. For instance, for the widths of the 42nd to 44th chamber of Nm. 2 (Fig. 6B), we obtained the same value (7.7 $\mathrm{mm}$ ), which presumably does not represent the actual width. This has been caused by the reduction in resolution resulting from segmenting only every 4th slice with an increment between two images $0.24 \mathrm{~mm}$ in voxel z (instead of $0.06 \mathrm{~mm}$; see the method section above for details). In addition to the low resolution, the obscure limit between chambers and septa at the edges of the chambers (on the flanks) in the slices might also have resulted in some errors in segmentation. However, the overall trend of the widths through ontogeny should still be correctly depicted and thus, the errors mentioned above were negligible for our study (Fig. 6B).

\section{DISCUSSION}

\section{Ontogenetic volumetric growth of ammonites}

Due to preservation and limited resolution, the chambers in the first two whorls of the Jurassic

234 ammonites could not be precisely measured. Therefore, the chamber numbers referred to below

235 were estimated based on recognizable chambers and more or less constant septal spacing. There 
appears to be a subtle point where the slope of the curves changes at around the 28 to 29 th

237

238

239

240

241

242

243

244

245

246

247

248

250

251

252

253

254

255

256

257

258

chamber (Fig. 2B), corresponding to a conch diameter of about $4.5 \mathrm{~mm}$. This change may

represent the end of the second growth stage of ammonoids, the neanic stage, because it has been reported that the neanic stage of ammonoids lasts until a conch diameter of 3-5 mm (Bucher et al., 1996). This point may have been related to the change of their mode of life, i.e. from planktonic to nektoplanktonic or nektonic (Arai \& Wani, 2012). Taking this into account, the first two whorls of the conch comprise the first two growth stages, namely the embryonic and the neanic stages (Bucher et al., 1996; Westermann, 1996; Klug, 2001). Note that since the volumes of chambers formed before the 25th and 27th in $\mathrm{Nm} .1$ and $\mathrm{Nm} .2$ have not been measured due to the poor resolution, the transition between the first two growth stages has not been examined. Naglik et al. (2015b) three-dimensionally examined three different Palaeozoic ammonoid species. They documented a change in the slope of growth trajectories around the 19th to 21 st chamber in each specimen. The last several chambers display fluctuating growth known as terminal countdown (Seilacher \& Gunji, 1993). In Nm. 2, an abrupt decrease of chamber volume occurred at the 45 th chamber, marking another trend resulting in a lower cumulative volume than in Nm. 1 . It is known that injuries can affect the septal spacing in modern Nautilus (Ward, 1985; compare Keupp \& Riedel, 1995) as well as in ammonoids (Kraft et al., 2008). However, there are no visible injuries on the conch of $\mathrm{Nm}$. 2, suggesting that this might have not been the case. Although the ammonite could have repaired a shell injury, it would be hard to recognize the presence of such a sublethal injury due to low resolution or the effects of shell replacement. Environmental changes might also have affected the conch construction. For example, in modern scleractinian corals, it is suggested that the $\mathrm{Mg} / \mathrm{Ca}$ ratio in the sea water alters the skeletal growth rate (Ries et al., 2006). The knowledge of the sedimentary facies of the host rock from which the 
ammonites were extracted is insufficient to identify possible causes for the alteration of shell growth. Another possibility is the presence of parasites such as tube worms. They might have grown on the external conch, which affected the buoyancy of the ammonite. Interestingly, Nm. 1 preserves the trace of a worm tube in the 41th chamber of the fifth whorl (Tajika et al., 2015), which had no detectable effect on chamber formation (Fig. 2A). Because of the absence of any trace of syn vivo epifauna on the conch, this scenario is unlikely.

The two different cumulative volumes of phragmocone chambers should result in a difference in buoyancy, given that the size of the two ammonites is more or less equal. The buoyancy of Nm. 1 was calculated by Tajika et al. (2015) as being positively buoyant in the (unlikely) absence of cameral liquid. Based on these calculations, they estimated the fill fraction of cameral liquid to attain neutral buoyancy as being about $27 \%$. Unfortunately, the incompleteness of the aperture of Nm. 2 does not permit to calculate the buoyancy. It is quite reasonable, however, to speculate that Nm. 2 requires slightly less cameral liquid to reach neutral buoyancy $(>27 \%)$ because of its size, its smaller phragmocone, and its most-likely similar conch mass. The fact that specimens with only minute morphological differences of the same species (Normannites mitis) likely expressed variation in buoyancy raises the question whether morphologically more diverse genera like Amaltheus (Hammer \& Bucher, 2006) also varied more strongly in buoyancy regulation.

\section{Ontogenetic volumetric growth of modern Nautilus and its intraspecific variation}

Landman et al. (1983) reported that the first seven septa of Recent Nautilus are more widely spaced than the following ones; the point where septal spacing changes lies between the 7th and 
281 8th chamber. It is considered to correspond to the time of hatching, which is also reflected in the

282 formation of a shell-thickening and growth halt known as the nepionic constriction. This feature

283 is also reported from fossil nautilids (Landman et al., 1983; Wani \& Ayyasami, 2009, Wani \&

284 Mapes, 2010).

In the growth trajectories of specimen 17 (Fig. 3A; Table 3), there are two abnormalities (the

5th and 6th chambers). These are supposedly artefacts caused by the low resolution of the scan

combined with the small size of these structures and the resulting course surface of extracted

chamber volume. This can occasionally cause some errors in calculating volumes in Matlab. But

this problem occurred only in specimen 17, even though the low resolution would have caused

errors in early rather than in late ontogeny.

Our results revealed a constant growth rate until the 5th or 6th chamber (Fig. 4B). Thereafter,

the growth changes to another constant growth rate. Differences in the position of the nepionic constriction may be the artefact of low resolution of the scan, which might have made the very first (and possibly the second) chamber invisible. The position of the nepionic constriction, however, has some intraspecific variation (Chirat, 2001). Stenzel (1964) and Landman et al. (1994) showed some septal crowding between septa number 4 and 5 and between 9 and 10, respectively. Taking this into account, it is likely that our results are reflections of intraspecific variation. Nevertheless, in each examined specimen, the chamber volumes fluctuate but typically increase until the appearance of the nepionic constriction (Table 3). At the mature growth stage, most specimens show a volume reduction of the last chamber. Variability in chamber volume could be a consequence of several factors that influence the rate of chamber formation (growth rate): temperature, $\mathrm{pH}$ (carbon saturation degree), trace elements, food availability, sexual 303 dimorphism, injuries, and genetic predisposition for certain metabolic features. 
A relevant model for shell growth may be the 'temperature size rule' (e.g., Atkinson, 1994;

Irie, 2010) which states the negative relationship between temperature and maturation size at moderate temperature, even though the growth rate slows down and the body size increases under extremely high or low temperatures. Rosa et al. (2012) observed a significant negative correlation between sea surface temperature and body size in coastal cephalopods. If this rule is applicable to the examined Nautilus, the temperature might have changed the growth rate of each individual because vertical migration of Nautilus is reported to range from near the sea surface to slightly below $700 \mathrm{~m}$ (Dunstan et al., 2011). Dunstan et al. (2011) also suggested that the strategy for vertical migration of geographically separated Nautilus populations may vary depending on the slope, terrain and biological community. At this point, it is hard to conclude whether or not the temperature size rule applies because the behaviour of Nautilus in the Philippines can be highly different from Australian Nautilus as reported by Dunstan et al. (2011). Knowledge of their behaviour or possible environmental preference during growth is necessary to examine this aspect. Westermann et al. (2004) described the period of chamber formation of Nautilus pompilius which ranges from 14 to more than 400 days. It is still likely that one individual inhabited different water depths from other individuals, producing varying trends of growth trajectories. Tracking the behaviour of modern Nautilus in the Philippines may provide more information on the role and applicability of the temperature size rule.

Analyses of stable isotopes have been used to estimate habitats of shelled animals (e.g., Landman et al., 1994; Moriya et al. 2003; Auclair et al., 2004; Lécuyer \& Bucher, 2006; Lukeneder et al., 2010; Ohno et al., 2015). It might be worthwhile to examine the isotopic composition of the shells of a few nautilid and ammonoid shells with different volumetric 
326 changes through ontogeny, because this may shed some light on the relationships between

327 habitat and growth trajectories.

328 The $\mathrm{pH}$ (or carbon saturation degree) influences shell secretion. A decrease of carbon

329 saturation causes a lack of $\mathrm{CO}_{3}{ }^{2-}$-ions, which are required to produce aragonitic or calcitic shells

330 (e.g., Ries et al., 2009). In Sepia officinalis, elevated calcification rates under hypercapnic

331 conditions have been shown by Gutowska et al. (2010). This change in $\mathrm{pH}$ may alter the time

332 needed to form a chamber and thereby reduce or increase the chamber volume. Similarly, trace

333 elements like the $\mathrm{Mg} / \mathrm{Ca}$ ratio in the sea water can affect the growth rate (for corals see, e.g., Ries

334 et al., 2006). Food availability (e.g., lack of food) is also a possible explanation for the great

335 variation. Wiedmann \& Boletzky (1982) showed a link between lack of food and lower growth

336 rates, resulting in closer septal spacing. Strömgren \& Cary (1984) demonstrated a positive

337 correlation between growth rate of mussels and food source. It is likely that there was at least

338 some competition for food between Nautilus individuals and probably also with other animals.

339 The individuals in a weaker position might have had access to less food or food of poorer quality.

340 Intraspecific variability can also originate from sexual dimorphism. In the case of Nautilus,

341 males tend to be slightly larger than females with slightly broader adult body chambers

342 (Hayasaka et al., 2010; Saunders \&Ward, 2010; Tanabe \& Tsukahara 2010). However, in the

343 juvenile stage, the morphological differences are not very pronounced, thus often hampering

344 sexing. The two average slopes in the curves of chamber volumes obtained from males and

345 females were compared using a test (analysis of the residual sum of squares: ARSS) described in

346 Zar (1996). This test was conducted independently for the embryonic stage and the other growth

347 stages since the critical point between the 5th and the 6th chamber changes the slope of the

348 growth curve (Fig. 4B). Moreover, an analysis of the residual sum of squares for nonlinear 
regressions was performed to compare the two average logistic models of males and females for the latter stage (Fig. 4C). No significant difference in the embryonic stage and a significant difference in the later stage (Table 5,6) suggest that the differentiation in chamber volume between both sexes begins immediately after hatching. The results (Fig. 4) also show, however, the occurrence of conch morphologies common to both sexes. Taking this into account, their volume is not an ideal tool for sexing. The same statistical test for linear regressions was also conducted to compare the number of formed chambers (Fig. 5A) and the phragmocone volume (Fig. 5B) with maximum conch diameter between male and female individuals. The test results (Table 5) suggest that there is a significant difference between the female and male in both cases, although the significance levels are not strict (the number of chambers vs. maximum diameter: $\mathrm{P}<0.05$ : the entire phragmocone volume vs. maximum diameter: $\mathrm{P}<0.1)$. A greater sample, however, may yield a clearer separation. The results of a series of statistical tests (Table 5; analyses of the residual sum of squares) suggest that the males tend to produce more chambers than females with nearly the same conch diameter. Bearing in mind that mature males are generally larger than mature females in maximum conch diameter (Hayasaka et al., 2010), this may potentially indicate a prolonged life span or less energetic investment in reproduction. By contrast, the addition of another chamber to males could be associated with their sexual maturity; the weight of the large spadix and a large mass of spermatophores in males might necessitate more space and buoyancy. Ward et al. (1977) reported that the total weight of males of Nautilus pompilius from Fiji exceeds that of females by as much as $20 \%$. What remains unclear is the reason why females tend to have larger phragmocone volumes than males while they are immature. It is true, however, that even within each sex, the variability of the total phragmocone volumes is quite high (standard deviation for males: 15.4; for females: 13.4; for both males and 
372 females: 14.3). Of course one should also bear in the possibility mind that these high variabilities

373 may have partially originated from the errors discussed in the method section.

374 Injuries are visible in several of the examined specimens, yet there is no link to a temporal or 375 spatial change in chamber volume in the growth curves. Yomogida \& Wani (2013) examined

376 injuries of Nautilus pompilius from the same locality in the Philippines, reporting traces of

377 frequent sublethal attacks rather early in ontogeny than in later stages. The frequency of

378 sublethal attacks early in ontogeny may be one of the factors determining the steepness of the

379 growth trajectory curves. This aspect can be tested in further studies. Additionally,

380 morphological variability may also root in genetic variability but the causal link is difficult to 381 test.

\section{Covariation of chamber volumes and widths in ammonoids and nautiloids}

384

385

The relationship between chamber volumes of Nautilus pompilius (Fig. 7) revealed that their chamber widths expanded at a constant pace irrespective of the change in chamber volume. For the construction of the Nautilus conch and its ontogeny, a rather constant conch morphology might have been advantageous with the buoyancy regulation depending largely on septal spacing only. Likewise, Hoffmann et al. (2015) reported on Spirula that has a sudden decrease of chamber volume which is not correlated with changes in whorl height or whorl width but with changes in septal spacing. By contrast, the chamber widths and volumes of the ammonites appear to covary (Fig. 6). This distinct covariation may have partially contributed to the high morphological variability with some constraints in response to fluctuating environmental conditions or predatory attacks (for details, see the discussion for Nautilus above). This aspect, 
394 however, needs to be examined further using an image stack of an ammonite with a higher

395 resolution and better preservation to rule out artefacts.

CONCLUSIONS

398

399

400

401

402

403

404

405

406

407

408

409

410

411

412

413

414

We virtually reconstructed the conchs of two Middle Jurassic ammonites (Normannites mitis) and 30 specimens of Recent nautilids (Nautilus pompilius) using grinding tomography and computed tomography (CT), respectively, to analyse the intraspecific variability in volumetric change of their chambers throughout ontogeny. The data obtained from the constructed 3D models led to the following conclusions:

1. Chamber volumes of Normannites mitis and Nautilus pompilius were measured to compare the ontogenetic change. The growth trajectories of Normannites mitis and Nautilus pompilius follow logistic curves throughout most of their ontogeny. The last several chambers of Normanites mitis show fluctuating chamber volumes, while most specimens of Nautilus pompilius demonstrate a volume reduction of only the last chamber.

2. Growth trajectories of the two Normannites mitis specimens were compared. The two specimens appear to have a transition point between the 28th and 29th chamber from which the slopes of their growth curves change, which has been documented previously. However, their entire phragmocone volumes differ markedly in late ontogeny although the two shells have similar morphology and size. Intraspecific variation of buoyancy was not testable in this study due to the low sample number. This aspect needs to be 
addressed in future research because buoyancy analyses could provide information on the habitat of ammonoids.

417 3. Growth trajectories of thirty Nautilus pompilius conchs show a high variability, even 418 though the high variabilitiy may have partially originated from the errors discussed in the method section.

4. Results of statistical tests for Nautilus pompilius corroborate that the variability is increased by the morphological difference between the two sexes: adult males have larger volumes than females with the same diameter. This may be ascribed to the formation of voluminous reproductive organs in the male (spadix). Individual chamber volumes of the female tend to be larger than those of males. The results also show that intraspecific variability within one sex is moderately strong. Examinations of their injuries, isotopic analyses of the examined conchs or tracking the behaviour of Nautilus could yield more information on the relationship between their variability in chamber volumes and ecology. Such data could help to reconstruct the palaeoecology of fossil nautiloids and possibly also of extinct ammonoids.

5. Covariation between the chamber widths and volumes in ammonites and Nautilus pompilius were examined. The results illustrate that conch construction of Nautilus pompilius is robust, maintaining a certain shape, whereas the conch development of the examined ammonites was more plastic, changing shape during growth under some fabricational constraints. Further investigations need to be carried out to verify the covariation between widths and volumes of ammonites with other variables such as conch thickness, conch width, and perhaps buoyancy using a reconstruction method with a higher resolution and perfectly-preserved materials. 
439 ACKNOWLEDGEMENT

440 We would like to thank Dominik Hennhöfer and Enric Pascual Cebrian (Universität Heidelberg)

441 for carrying out the grinding tomography. Beat Imhof (Trimbach) kindly donated the two

442 specimens of Normannites. We are also thankful to Torsten Scheyer (Universität Zürich) for the

443 introduction to the use of Avizo ${ }^{\circledR}$ 8.1. Kathleen Ritterbush (University of Chicago) proofread the

444 manuscript and corrected the English. The fruitful discussion with Kozue Nishida (The

445 Geological Survey of Japan) is greatly appreciated.

446

447

448 


\section{REFERENCES}

450

451

452

453

454

455

456

457

458

459

460

461

462

463

464

465

466

467

Akamine T. 2004. Statistical test and model selection of fish growth formula. Bulletin of the Japanese Society of Fisheries Oceanography 68(1):44-51.

Arai K, Wani R. 2012. Variable growth modes in late cretaceous ammonoids: implications for diverse early life histories. Journal of Paleontology 86:258-267.

Arnold JM. 1984. Cephalopod reproduction. In Biggelar, ed. The Mollusca. New York: Academic Press, 7:419-454.

Atkinson D. 1994. Temperature and organism size—a biological law for ectotherms? Advances in Ecological Research 25:1-58.

Auclair AC, Lécuyer C, Bucher H, Sheppard SMF. 2004. Carbon and oxygen isotope composition of Nautilus macromphalus: a record of thermocline waters off New Caledonia. Chemical Geology 207:91-100.

Bucher H, Landman NH, Klofak SM, Guex J. 1996. Mode and rate of growth in ammonoids. In Landman NH, Tanabe K, Davis RA, eds. Ammonoid paleobiology. New York; Plenum, $407-461$.

Chirat R. 2001. Anomalies of embryonic shell growth in post-Triassic Nautilida. Paleobiology 27:485-499.

Collins D, Ward PD, Westermann GEG. 1980. Function of cameral water in Nautilus. Paleobiology 6:168-172. 
Dunstan AJ, Ward PD, Marshall NJ. 2011. Vertical distribution and migration patterns of Nautilus pompilius. PloS one 6(2):e16311.

Garwood RJ, Rahman IA, Sutton MD. 2010. From clergymen to computers - the advent of virtual palaeontology. Geology Today 26:96-100.

Gutowska MA, Melzner F, Langenbuch M, Bock C, Claireaux G, Pörtner HO. 2010. Acidbase regulatory ability of the cephalopod (Sepia officinalis) in response to environmental hypercapnia. Journal of Comparative Physiology B 180:323-335.

Götz S. 2003. Larval settlement and ontogenetic development of Hippuritella vasseuri (Douvillé) (Hippuritoidea, Bivalvia). Geologia Croatica 56(2):123-131.

Götz S. 2007. Inside rudist ecosystems: growth, reproduction and population dynamics. In: Scott RW, editor. Cretaceous rudists and carbonate platforms: environmental feedback. SEPM Special Publication 87. Tulsa (OK): Society for Sedimentary Geology 97-113.

Götz S, Stinnesbeck W. 2003. Reproductive cycles, larval mortality and population dynamics of a Late Cretaceous hippuritid association: a new approach to the biology of rudists based on quantitative three dimensional analysis. Terra Nova 15:392-397.

Hammer Ø, Bucher H. 2006. Generalized ammonoid hydrostatics modelling, with application to Intornites and intraspecific variation in Amaltheus. Palaeontological Research 10:91-96.

Haven N. 1977. The reproductive biology of Nautilus pompilius in the Philippines. Marine Biology 42(2): 177-184. 
487

488

489

Hayasaka S, Ōki K, Tanabe K, Saisho T, Shinomiya A. 2010. On the habitat of Nautilus pompilius in Tanon Strait (Philippines) and the Fiji Islands. In Saunders WB, Landman NH, eds. Nautilus. The Biology and Paleobiology of a living fossil. Springer: Dordrecht, 179-200.

Hennhöfer DK, Götz S, Mitchell SF .2012. Palaeobiology of a Biradiolites mooretownensis rudist lithosome: seasonality, reproductive cyclicity and population dynamics. Lethaia 45:450-461.

Hoffmann R, Zachow S. 2011. Non-invasive approach to shed new light on the buoyancy business of chambered cephalopods (Mollusca). In Proceedings IAMG 507-517 DOI 10.5242/iamg.2011.0163.

\section{Hoffmann R, Schultz JA, Schellhorn R, Rybacki E, Keupp H, Gerden SR, Lemanis R,} Zachow S. 2014. Non-invasive imaging methods applied to neo- and paleontological cephalopod research. Biogeosciences Discussions 10:18803-18851.

Hoffmann R, Reinhoff D, Lemanis R. 2015. Non-invasive imaging techniques combined with morphometry: a case study from Spirula. Swiss Journal of Palaeontology DOI

$$
10.1007 / \mathrm{s} 13358-015-0083-0 .
$$

Irie T. 2010. Adaptive significance of the temperature-size rule. Japanese Journal of Ecology 60:169-181.

Jacobs DK, Landman NH. 1993. Nautilus - a poor model for the function and behavior of ammonoids?. Lethaia 26:101-111.

Keupp H, Riedel F. 1995. Nautilus pompilius in captivity: a case study of abnormal shell growth. Berliner geowissenschaftliche Abhandlungen E16:663-681. 
Klug C. 2001. Life-cycles of Emsian and Eifelian ammonoids (Devonian). Lethaia 34:215-233.

509

510

511

512

513

514

515

516

517

518

519

520

521

522

523

524

525

526

527

528

Klug C. 2004. Mature modifications, the black band, the black aperture, the black stripe, and the periostracum in cephalopods from the Upper Muschelkalk (Middle Triassic, Germany). Mitteilungen aus dem Geologisch-Paläontologischen Institut der Universität Hamburg 88:63-78.

Klug C, Zatoń M, Parent H, Hostettler B, Tajika A. 2015. Mature modifications and sexual dimorphism. In Klug C, Korn D, De Baets K, Kruta I, Mapes RH, eds. Ammonoid paleobiology, Volume I: from anatomy to ecology. Topics in Geobiology 43.Dordrecht; Springer, 252-320.

Korn D, Bockwinkel J, Ebbighausen V. 2010. The ammonoids from the Argiles de Teguentour of Oued Temertasset (early Late Tournaisian; Mouydir, Algeria). Fossil Record 13:35-152.

Kraft S, Korn D, Klug C. 2008. Ontogenetic patterns of septal spacing in Carboniferous ammonoids. Neues Jahrbuch für Geologie und Mineralogie, Abhandlungen 250:31-44.

Kruta I, Landman N, Rouget I, Cecca F, Tafforeau P. 2011. The role of ammonites in the Mesozoic marine food web revealed by jaw preservation. Science 331:70-72.

Landman NH, Rye DM, Shelton KL. 1983. Early ontogeny of Eutrephoceras compared to Recent Nautilus and Mesozoic ammonites: evidence from shell morphology and light stable isotopes. Paleobiology 9:269-279.

Landman NH, Cochran JK, Rye DM, Tanabe K, Arnold JM. 1994. Early Life History of Nautilus: Evidence from Isotopic Analyses of Aquarium-Reared Specimens. Paleobiology 20:40-51. 
529 Lemanis R, Zachow S, Fusseis F, Hoffmann R. 2015. A new approach using high-resolution

530 computed tomography to test the buoyant properties of chambered cephalopod shells.

$531 \quad$ Paleobiology 41:313-329.

532 Lécuyer C, Bucher H. 2006. Stable isotope compositions of a late Jurassic ammonite shell: a

533 record of seasonal surface water temperatures in the southern hemisphere? eEarth Discuss

$534 \quad 1: 1-19$.

535

536

537

538

539

540

541

542

543

544

545

546

547

548

Lukeneder A, Harzhauser M, Müllegger S, Piller WE. 2010. Ontogeny and habitat change in Mesozoic cephalopods revealed by stable isotopes $\left(\delta^{18} \mathrm{O}, \delta^{13} \mathrm{C}\right)$. Earth and Planetary Science Letters 296:103-114.

Moriya K, Nishi H, Kawahata H, Tanabe K, Takayanagi Y. 2003. Demersal habitat of Late Cretaceous ammonoids: Evidence from oxygen isotopes for the Campanian (Late Cretaceous) northwestern Pacific thermal structure. Geology 31:167-170.

Naglik C, Rikhtegar F, Klug C. 2015a. Buoyancy of some Palaeozoic ammonoids and their hydrostatic properties based on empirical 3D-models. Lethaia. DOI 10.1111/let.12125.

Naglik C, Monnet C, Götz S, Kolb C, De Baets K, Tajika A, Klug C. 2015b. Growth trajectories of some major ammonoid sub - clades revealed by serial grinding tomography data. Lethaia 48:29-46.

Ohno A, Miyaji T, Wani R. 2015. Inconsistent oxygen isotopic values between on temporary secreted septa and outer shell walls in modern Nautilus. Lethaia 48:332-340.
DOI10.1111/let.12109. 
549

550

551

552

Pascual-Cebrian E, Hennhöfer DK, Götz S. 2013. 3D morphometry of polyconitid rudist bivalves based on grinding tomography. Facies 59:347-358.

Reyment RA. 1958. Some factors in the distribution of fossil Cephalopods. Acta Universitatis Stockholmiensis - Stockholm Contributions in Geology 1 97-184.

Ries JB, Stanley SM, Hardie LA. 2006. Scleractinian corals produce calcite, and grow more slowly, in artificial Cretaceous seawater. Geology 34:525-528.

Ries JB, Cohen AL, McCorkle DC. 2009. Marine calcifiers exhibit mixed responses to CO2induced ocean acidification. Geology 37:1131-1134.

Rosa R, Gonzalez L, Dierssen HM, Seibel BA. 2012. Environmental determinants of latitudinal size-trends in cephalopods. Marine Ecology Progress Series 464:153-165.

Saunders WB, Spinosa C. 1978. Sexual dimorphism in Nautilus from Palau. Paleobiology $4: 349-358$.

Saunders WB, Ward PD. 2010. Ecology, distribution, and population characteristics of Nautilus. In Saunders WB, Landman NH, eds. Nautilus. The Biology and Paleobiology of a living fossil. Dordrecht: Springer, 137-162.

Saunders WB, Landman NH. 1987. Nautilus: The Biology and Paleobiology of a Living Fossil. New York: Plenum.

Seilacher A, Gunji YP. 1993. Morphogenetic countdown: another view on heteromorph shells in gastropods and ammonites. Neues Jahrbuch für Geologie und Paläontologie Abhandlungen 190:237-265. 
569 Stenzel HB. 1964. Living Nautilus. In Moore, RC, ed. Treatise on Invertebrate Paleontology.

570 Part K (Mollusca 3):K59-K93. Lawrence: Geological Society of America and University of

$571 \quad$ Kansas Press.

572 Stevens K, Mutterlose J, Wiedenroth K. 2015. Stable isotope data $(\delta 18 \mathrm{O}, \delta 13 \mathrm{C})$ of the

573 ammonite genus Simbirskites - implications for habitat reconstructions of extinct cephalopods.

$574 \quad$ Palaeogeography, Palaeoclimatology, Palaeoecology 417:164-175.

575 Strömgren T, Cary C. 1984. Growth in length of Mytilus edulis L. fed on different algal diets.

576 Journal of experimental marine biology and ecology 76:23-34.

577 Sutton M, Rahman I, Garwood R. 2014. Techniques for Virtual Palaeontology. Chichester:

$578 \quad$ Wiley-Blackwell.

579

580

581

582

\section{Tajika A, Naglik C, Morimoto N, Pascual-Cebrian E, Hennhöfer D, Klug C. 2015.}

Empirical 3D model of the conch of the Middle Jurassic ammonite microconch Normannites: its buoyancy, the physical effects of its mature modifications and speculations on their function. Historical Biology 27:181-191.

Tanabe K, Tsukahara J. 2010. Biometric analysis of Nautilus pompilius from the Philippines and the Fiji Islands. In Saunders WB, Landmann NH, eds. Nautilus: The Biology and Paleobiology of a Living Fossil. Dordrecht: Springer, 105-113..

Tanabe K, Hayasaka S, Saisho T, Shinomiya A, Aoki K. 1983. Morphologic variation of Nautilus pompilius from the Philippines and Fiji islands. Studies of Nautilus pompilius and its associated fauna from Tanon Strait, the Philippines. Kagoshima University Research Center for the Pacific Islands, Occasional Paper 1:9-21. 
Wani R. 2004. Experimental fragmentation patterns of modern Nautilus shells and the implications for fossil cephalopod taphonomy. Lethaia 37:113-123.

Wani R, Ayyasami K. 2009. Ontogenetic change and intra-specific variation of shell morphology in the Cretaceous nautiloid (Cephalopoda, Mollusca) Eutrephoceras clementinum (d'Orbigny, 1840) from the Ariyalur area, southern India. Journal of Paleontology 83:365378.

Wani R, Mapes RH. 2010. Conservative evolution in nautiloid shell morphology; evidence from the Pennsylvanian nautiloid Metacoceras mcchesneyi from Ohio, USA. Journal of Paleontology 84:477-492.

Ward PD. 1979. Cameral liquid in Nautilus and ammonites. Paleobiology 5:40-49.

Ward PD. 1980. Comparative shell shape distributions in Jurassic-Cretaceous ammonites and Jurassic-Tertiary nautilids. Paleobiology 6:32-43.

Ward PD. 1985. Periodicity of chamber formation in chambered cephalopods: evidence from Nautilus macromphalus and Nautilus pompilius. Paleobiology 11:438-450.

Ward PD. 1987. The natural history of Nautilus. Boston: Allen and Unwin.

Ward PD. 1988. In search of Nautilus. New York: Simon \& Schuster.

Ward P, Martin AW. 1978. On the buoyancy of the pearly Nautilus. Journal of Experimental Zoology 205:5-12. 
608 Ward P, Stone R, Westermann G, Martin A. 1977. Notes on animal weight, cameral fluids, 609 swimming speed, and colour polymorphism of the cephalopod Nautilus pompilius in the Fiji $610 \quad$ Islands. Paleobiology 3:377-388.

611

612

Warnke K, Keupp H. 2005. Spirula - a window to the embryonic development of ammonoids? Morphological and molecular indications for a palaeontological hypothesis. Facies 51:60-65.

Westermann GEG. 1996. Ammonoid life and habitat. In Landman NH, Tanabe K, Davis RA, eds. Ammonoid paleobiology. New York: Plenum, 607-707.

\section{Westermann B, Beck-Schildwächter I, Beuerlein K, Kaleta EF, Schipp R. 2004. Shell} growth and chamber formation of aquarium-reared Nautilus pompilius (Mollusca, Cephalopoda) by X - ray analysis. Journal of Experimental Zoology Part A: Comparative Experimental Biology 301:930-937.

Wiedmann J, Boletzky SV. 1982. Wachstum und Differenzierung des Schulps von Sepia officinialis unter künstlichen Aufzuchtbedingungen-Grenzen der Anwendung im palökologischen Modell. Neues Jahrbuch für Geologie und Paläontologie Abhandlungen 164:118-133.

\section{Wormanns D, Kohl G, Klotz E, Marheine A, Beyer F, Heindel W, Diederich S. 2004.} Volumetric measurements of pulmonary nodules at multi-row detector CT: in vivo reproducibility. European radiology 14:86-92.

Yomogida S, Wani R. 2013. Higher risk of fatality by predatory attacks in earlier ontogenetic stages of modern Nautilus pompilius in the Philippines: evidence from the ontogenetic analyses of shell repairs. Lethaia 46:317-330. 
629 Zar JH. 1996. Biostatistical analysis Third edition. Upper Saddle River: Prentice Hall.

630

631 


\section{CAPTIONS}

633 Figure $13 \mathrm{D}$ reconstructions of the two specimens of Normannites mitis, modern Nautilus 634 pompilius (specimen 17), and their phragmocones. (1A) 3D model of Normannites mitis (Nm. 1); 635 (1B) 3D model of Normannites mitis (Nm. 2); (1C) extracted phragmocone of Nm. 1 (1C); 636 extracted phragmocone of Nm. 2; (2A, B) 3D models of Nautilus pompilius (specimen 17); (2C) 637 extracted phragmocone of Nautilus pompilius (specimen 17); (2D) Backface of 3D model of 638 Nautilus pompilius (specimen 17). Scale bars are $1 \mathrm{~cm}$.

Figure 2 Volumes plotted against chamber numbers in Normannites mitis. The volumes prior to 641 chamber 25 (Nm. 1) and 27 (Nm. 2) have not been measured. (A) Scatter plot of chamber 642 numbers and individual chamber volumes; (B) Scatter plot of chamber numbers and cumulative 643 phragmocone volumes.

644

Figure 3 Chamber volumes plotted against chamber numbers in all examined Nautilus pompilius. (A) Scatter plot of chamber numbers and individual chamber volumes; (B) Scatter 647 plot of chamber numbers and phragmocone volumes.

Figure 4 Comparison between males and females. Chamber volumes plotted against chamber numbers in Nautilus pompilius. Squares and diamonds represent the female and male, respectively. (A) Scatter plot of chamber numbers and individual volumes; (B) Semilog scatter 
652 plot of chamber numbers and individual volumes; (C) Scatter plot of chamber numbers and 653 cumulative phragmocone volumes.

654

655 Figure 5 Comparison between males and females. Squares, diamonds, and triangles represent 656 the female, male, and indeterminable sex, respectively. (A) Scatter plot of maximum conch 657 diameters and chamber numbers of a specimen; (B) Scatter plot of maximum conch diameters 658 and the phragmocone volume.

Figure 6 Volumes and widths of chambers plotted against chamber numbers in Normannites mitis. Squares and diamonds represent volumes and widths, respectively. (A) Nm.1; (B) Nm. 2.

662

Figure 7 Volumes and widths of chambers plotted against chamber numbers in Nautilus pompilius. Squares and diamonds represent volumes and widths, respectively. (A) Specimen 8;

(B) Specimen 7; (C) Specimen 53. Specimens with different growth trajectories were analysed.

Table 1 Details of the studied specimens, Normannites mitis from the Middle Jurassic, 668 Switzerland, and modern Nautilus pompilius from the Philippines.

Table 2 Raw data of measured chamber volumes and widths in Normannites mitis. 
672 Table 3 Raw data of measured chamber volumes in Nautilus pompilius.

674 Table 4 Raw data of measured chamber widths of Nautilus pompilius.

676 Table 5 Results of statistical tests (analyses of the residual sum of squares) comparing linear

677 regressions of males and female. N, number of samples; RSS; residual sum of squares; DF, 678 degree of freedom; ns, not significant; s; significant.

679 Table 6 Results of a statistical test (an analysis of the residual sum of squares) comparing 680 nonlinear regressions of males and females. RSS; residual sum of squares; DF, degree of 681 freedom; ns, not significant; s; significant.

682 Supplemental Table Estimated errors resulting from CT scans in Nautilus pompilius. Actual 683 shell volumes were calculated based on measurement of weight of specimens with possible 684 minimum shell density (2.54 g/cm³ ; Hoffmann \& Zachow, 2011) and maximum shell density $685\left(2.62 \mathrm{~g} / \mathrm{cm}^{3}\right.$; Reyment, 1958) of Nautilus. 
Figure $\mathbf{1}_{\text {(on next page) }}$

$3 \mathrm{D}$ reconstructions of the two specimens of Normannites mitis, modern Nautilus pompilius (specimen 17), and their phragmocones.

(1A) 3D model of Normannites mitis (Nm. 1); (1B) 3D model of Normannites mitis (Nm. 2);

(1C) extracted phragmocone of Nm. 1 (1C); extracted phragmocone of Nm. 2; (2A, B) 3D models of Nautilus pompilius (specimen 17); (2C) extracted phragmocone of Nautilus pompilius (specimen 17); (2D) Backface of 3D model of Nautilus pompilius (specimen 17). Scale bars are $1 \mathrm{~cm}$. 
Figure 2 (on next page)

Volumes plotted against chamber numbers in Normannites mitis. The volumes prior to chamber 25 (Nm. 1) and 27 (Nm. 2) have not been measured.

(A) Scatter plot of chamber numbers and individual chamber volumes; (B) Scatter plot of chamber numbers and cumulative phragmocone volumes. 

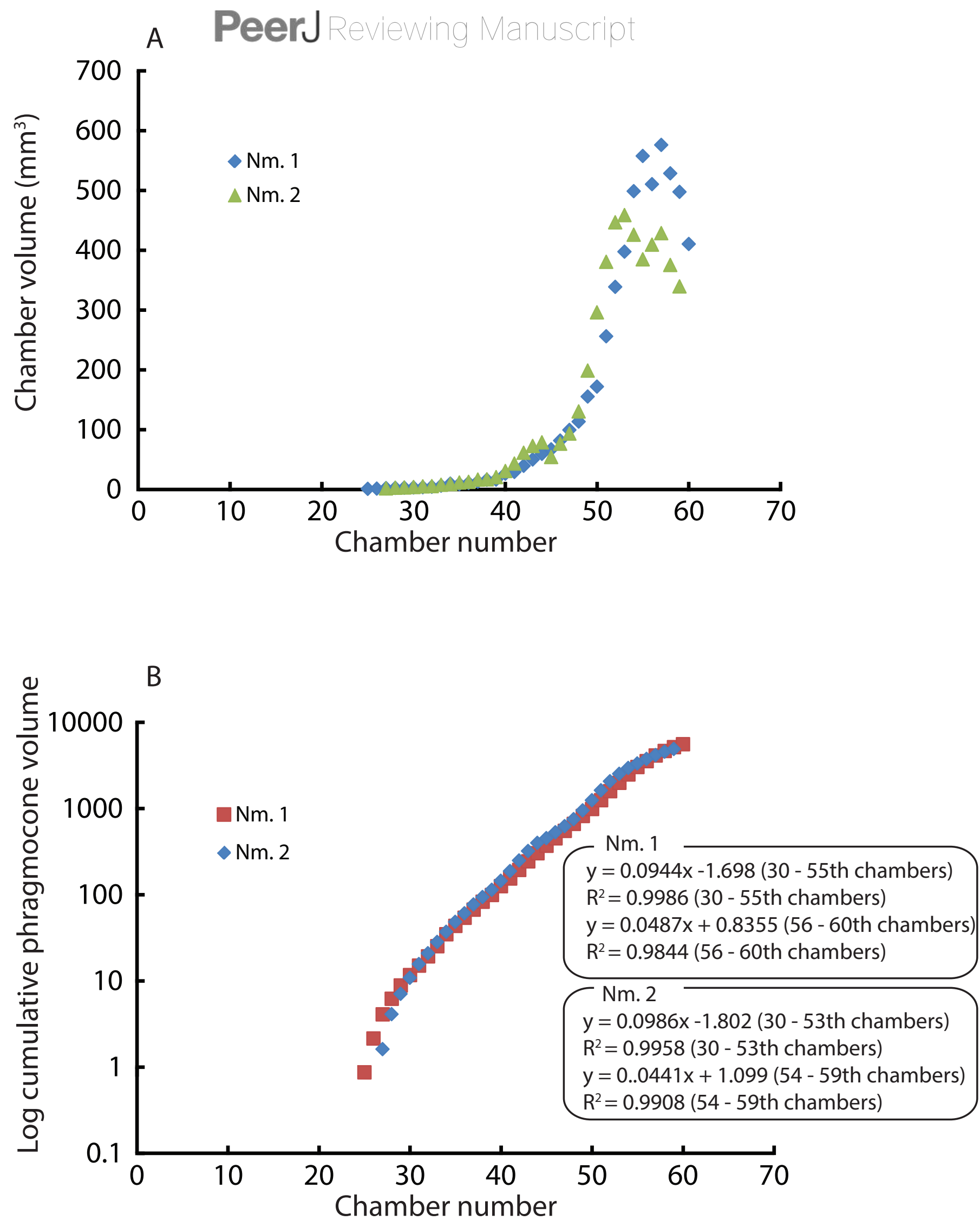
Figure 3 (on next page)

Chamber volumes plotted against chamber numbers in all examined Nautilus pompilius.

(A) Scatter plot of chamber numbers and individual chamber volumes; (B) Scatter plot of chamber numbers and phragmocone volumes. 


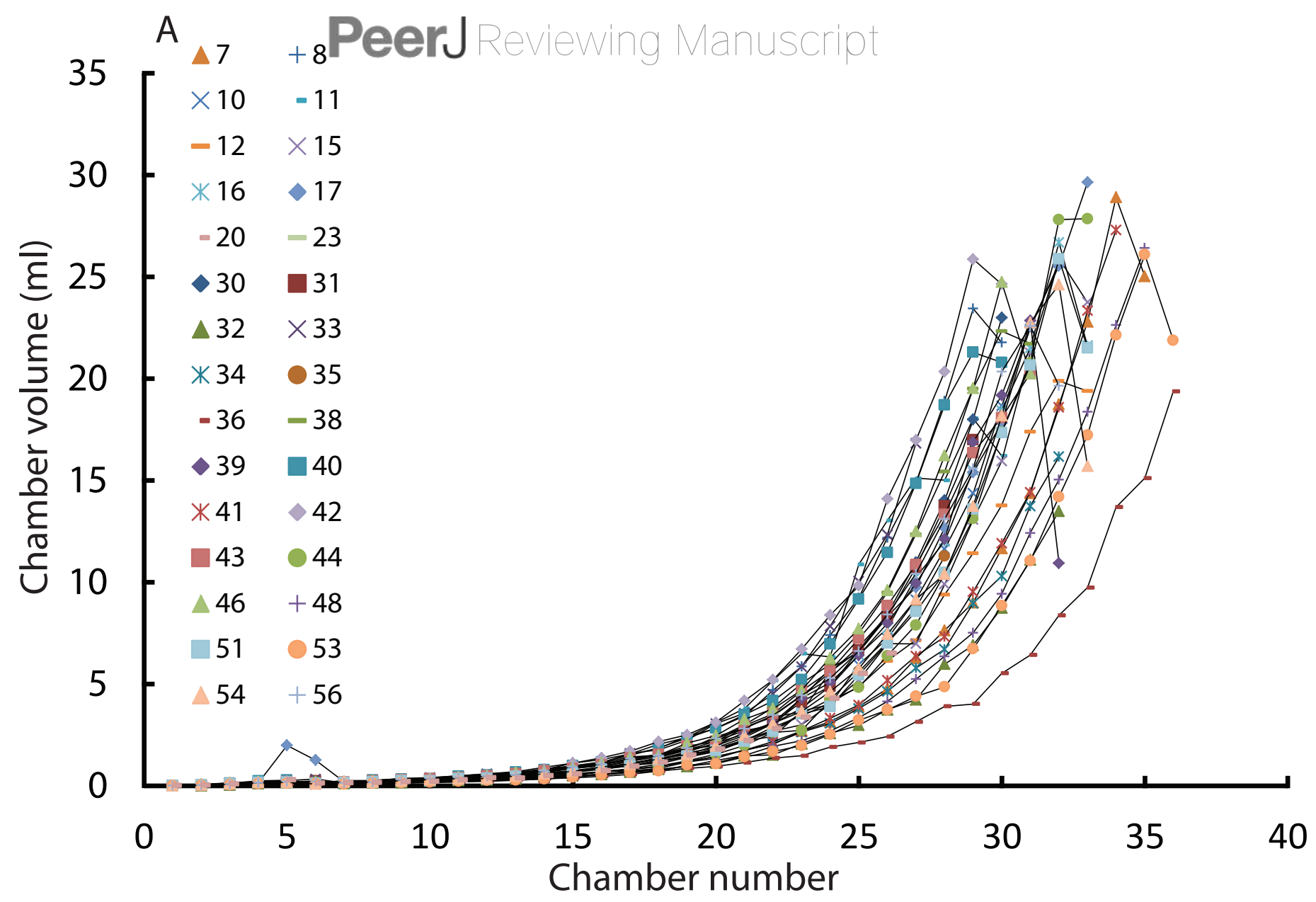

B

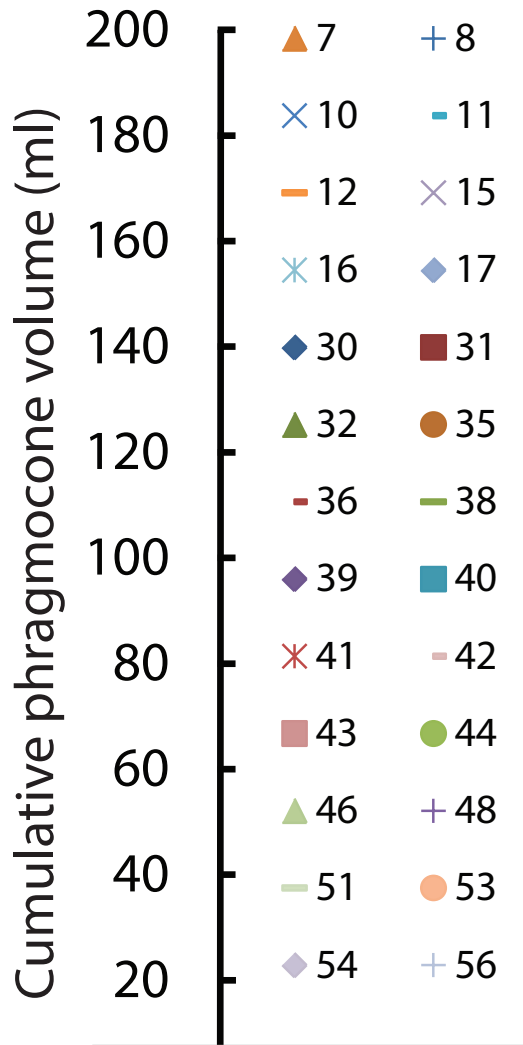

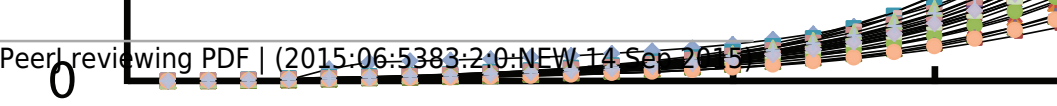


Figure 4 (on next page)

Comparison between males and females. Chamber volumes plotted against chamber numbers in Nautilus pompilius. Squares and diamonds represent the female and male, respectively.

(A) Scatter plot of chamber numbers and individual volumes; (B) Semilog scatter plot of chamber numbers and individual volumes; (C) Scatter plot of chamber numbers and cumulative phragmocone volumes. 

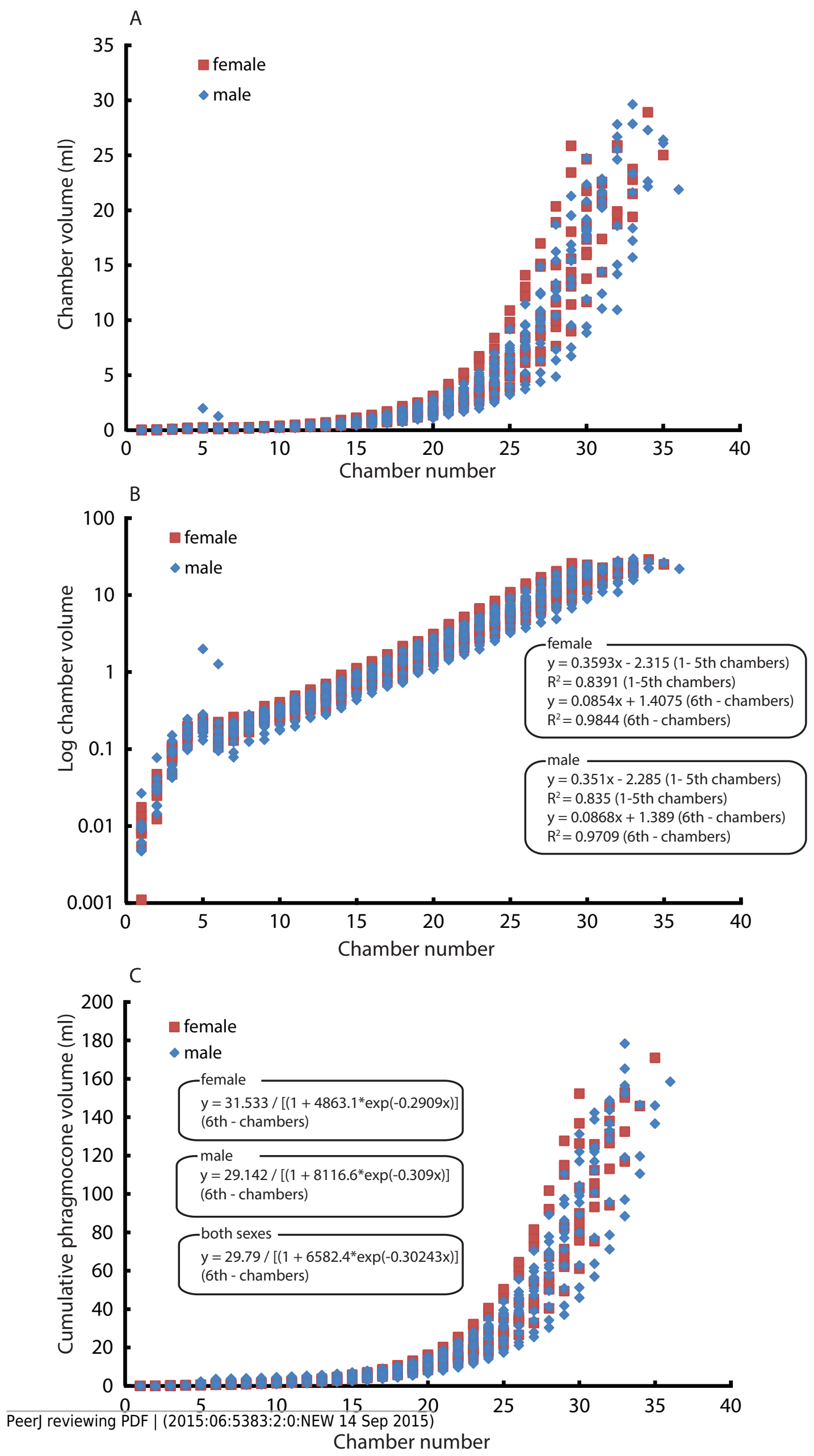
Figure 5 (on next page)

Comparison between males and females. Squares, diamonds, and triangles represent the female, male, and indeterminable sex, respectively.

(A) Scatter plot of maximum conch diameters and chamber numbers of a specimen; (B) Scatter plot of maximum conch diameters and the phragmocone volume. 

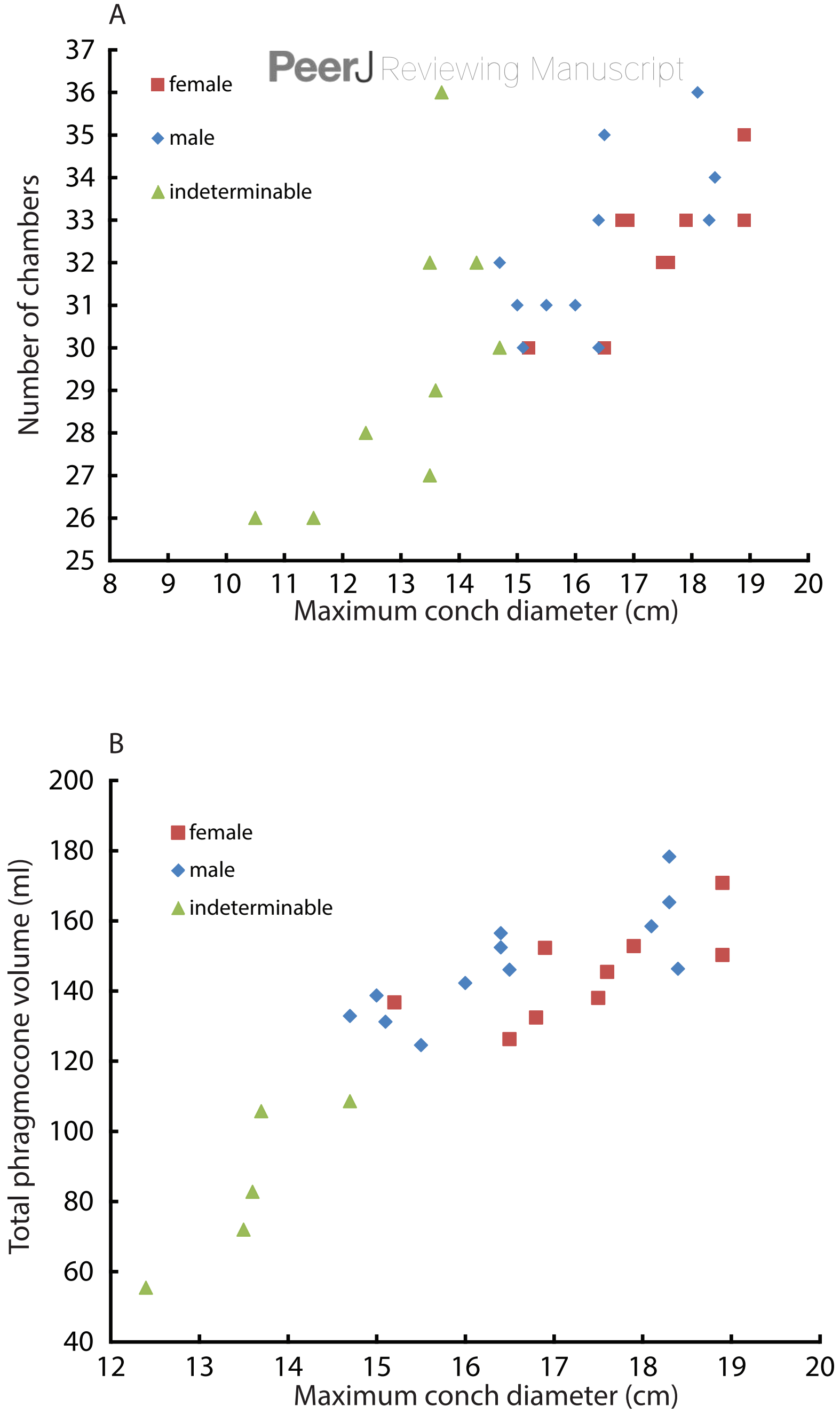
Figure 6 (on next page)

Volumes and widths of chambers plotted against chamber numbers in Normannites mitis. Squares and diamonds represent volumes and widths, respectively.

(A) Nm.1; (B) Nm. 2. 

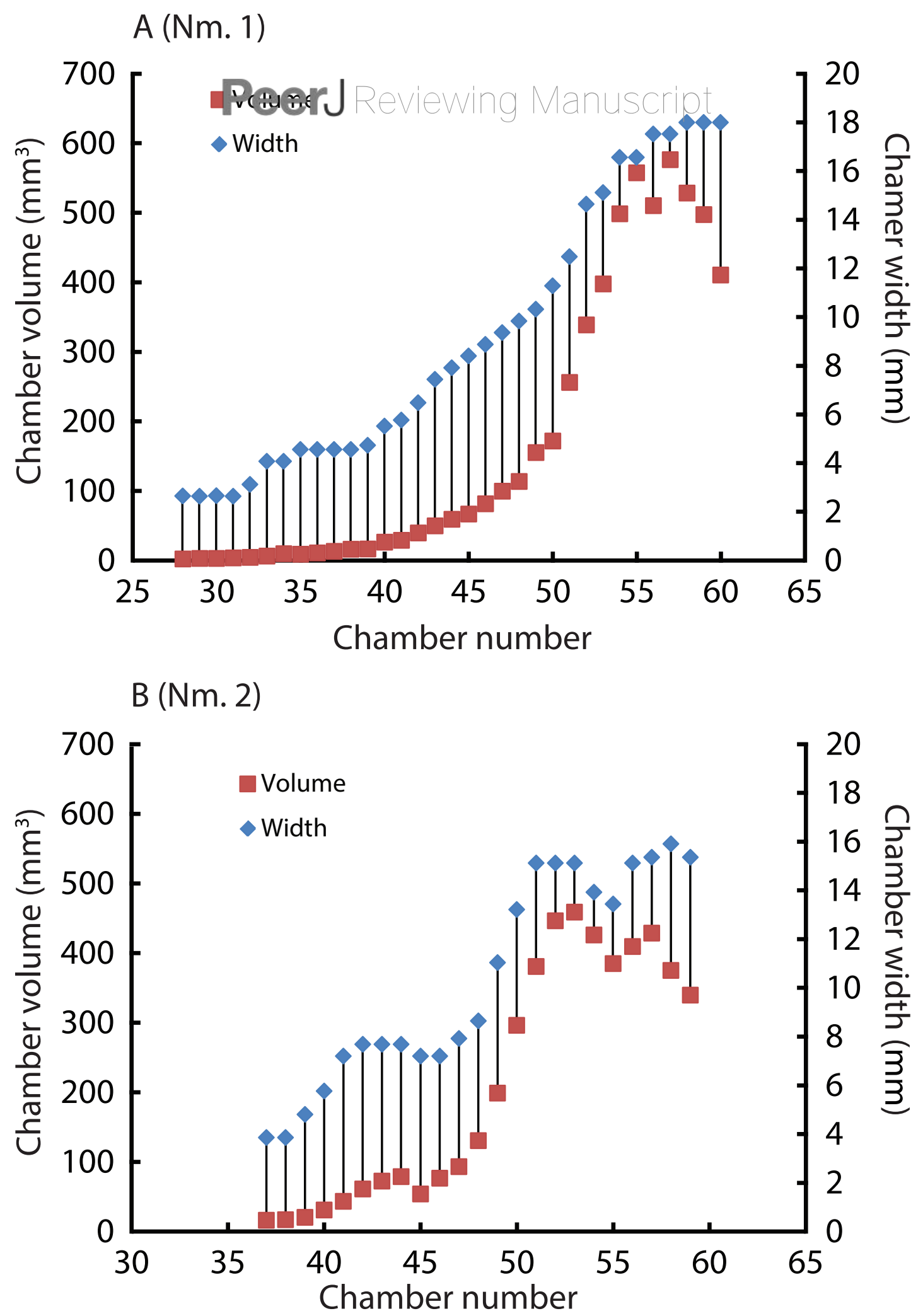
Figure 7 (on next page)

Volumes and widths of chambers plotted against chamber numbers in Nautilus pompilius. Squres and diamonds represent volumes and widths, respectively.

(A) Specimen 8; (B) Specimen 7; (C) Specimen 53. Specimens with different growth trajectories were analysed. 
A (specimen 8)

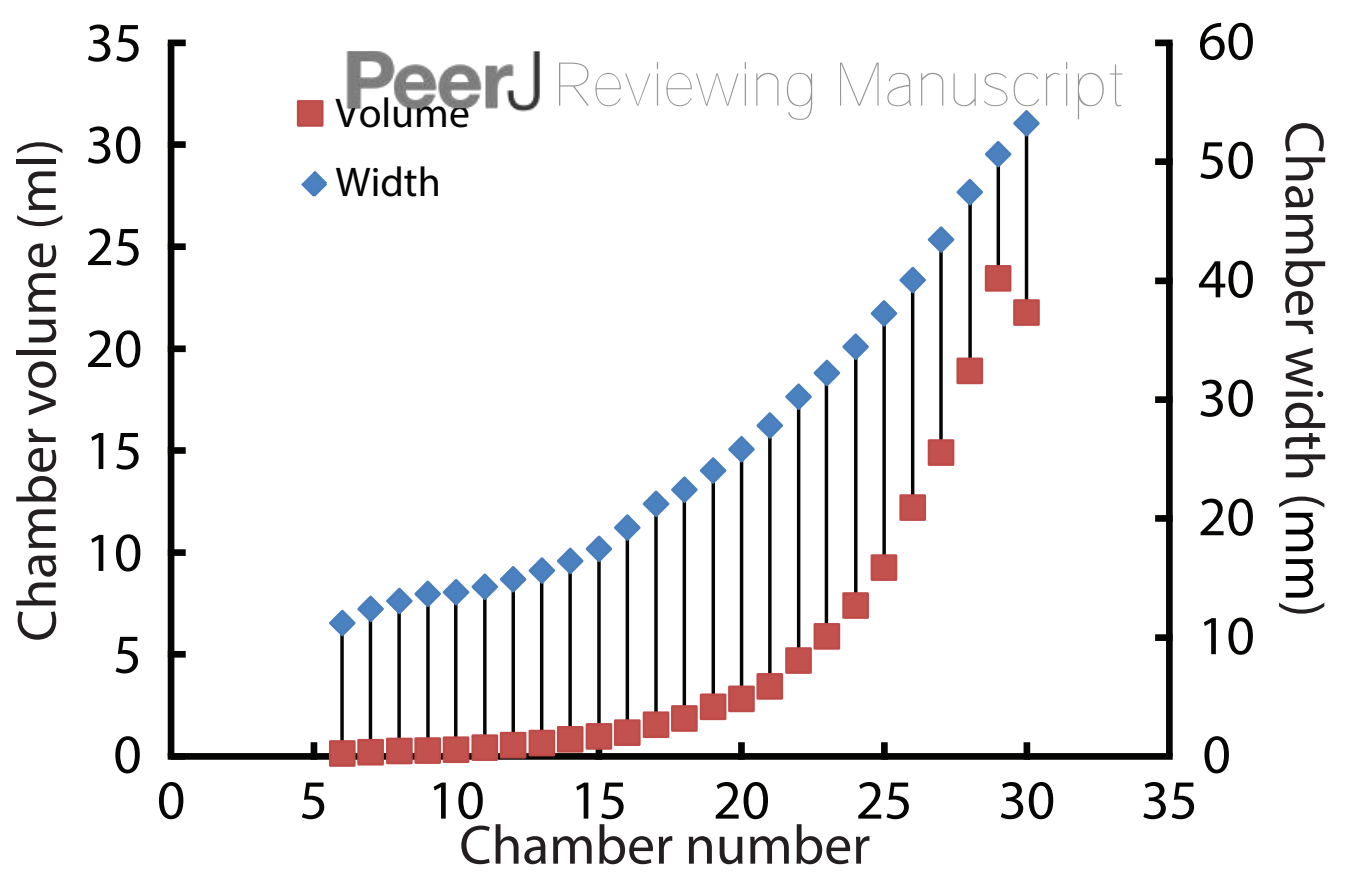

B (specimen 7)

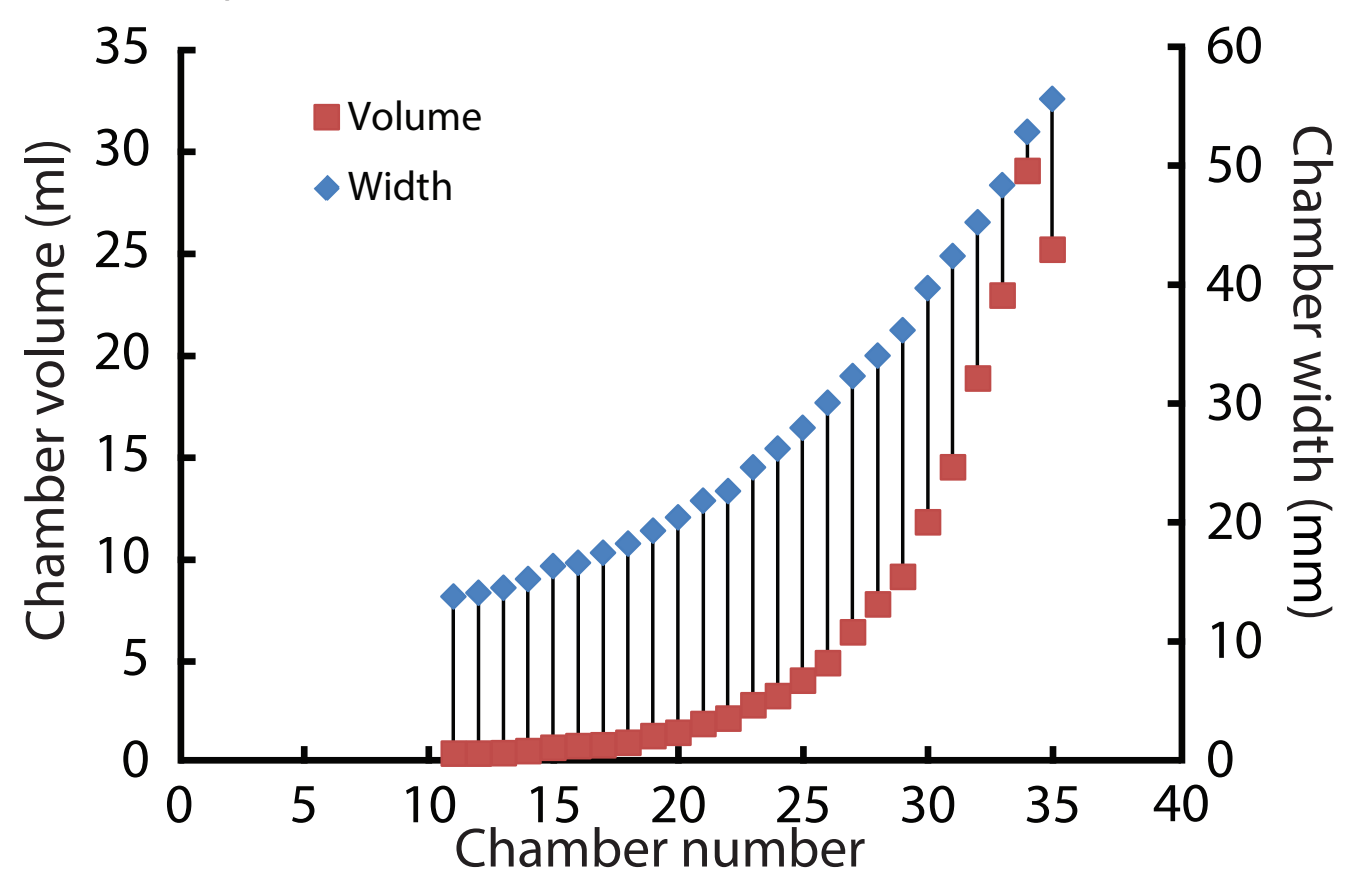

C (specimen 53)

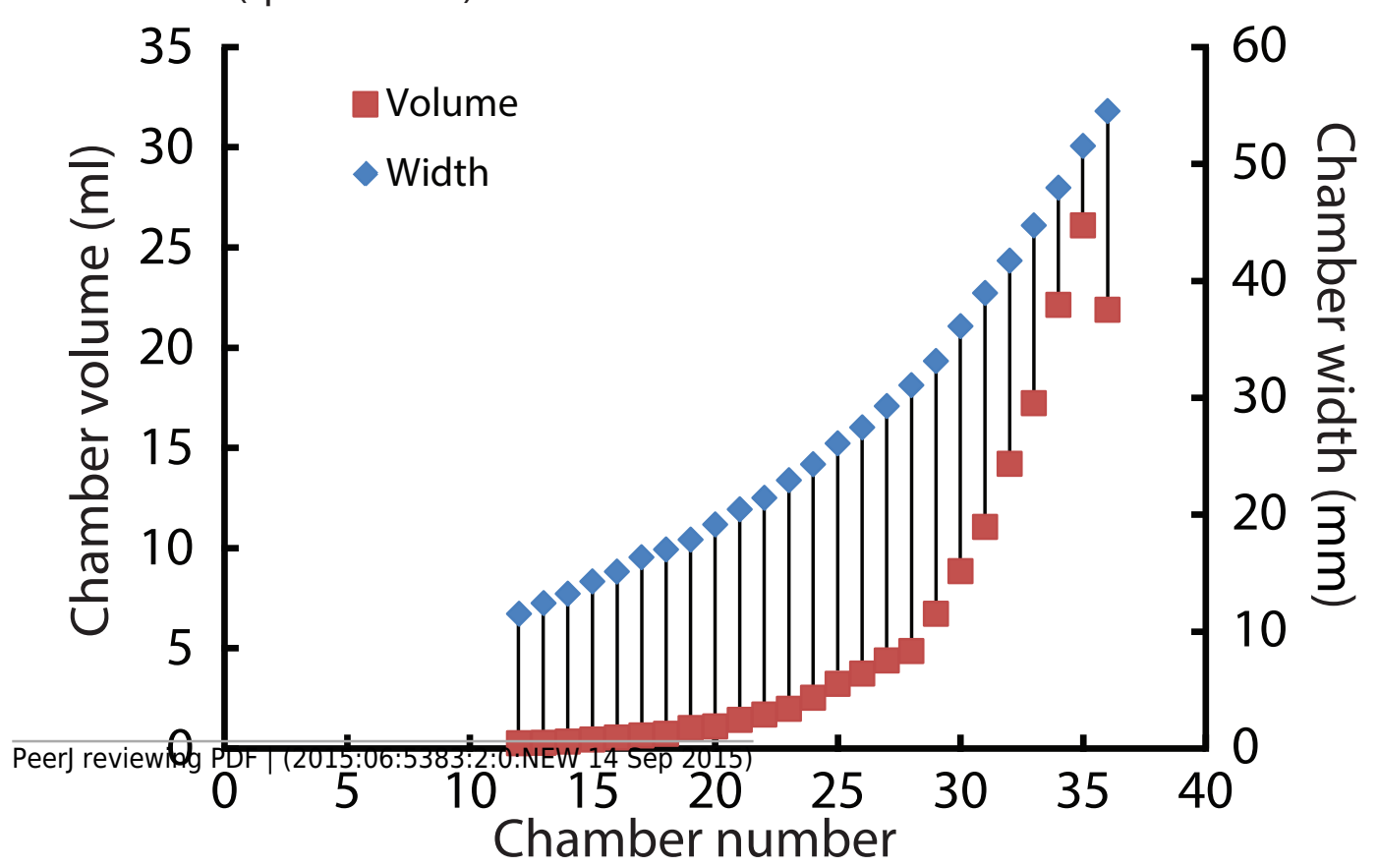




\section{Table $\mathbf{1}$ (on next page)}

Details of the studied specimens, Normannites mitis from the Middle Jurassic, Switzerland, and modern Nautilus pompilius from the Philippines. 


\begin{tabular}{|c|c|c|c|c|c|}
\hline $\begin{array}{l}\text { Specimen } \\
\text { number }\end{array}$ & Species & Maturity & Sex & $\begin{array}{c}\text { Maximum } \\
\text { diameter }(\mathrm{mm})\end{array}$ & $\begin{array}{l}\text { Number of } \\
\text { chambers }\end{array}$ \\
\hline $\mathrm{Nm} .1$ & Normannites mitis & Mature & Male & 50 & $60 ?$ \\
\hline $\mathrm{Nm} .2$ & Normannites mitis & Mature & Male & 49 & $59 ?$ \\
\hline 7 & Nautilus pompilius & Mature & Female & 189 & 35 \\
\hline 8 & Nautilus pompilius & Mature & Female & 152 & 30 \\
\hline 10 & Nautilus pompilius & Mature & Female & 175 & 32 \\
\hline 11 & Nautilus pompilius & Mature & Female & 165 & 30 \\
\hline 12 & Nautilus pompilius & Mature & Female & 168 & 33 \\
\hline 15 & Nautilus pompilius & Mature & Female & 189 & 33 \\
\hline 16 & Nautilus pompilius & Mature & Male & 183 & 33 \\
\hline 17 & Nautilus pompilius & Mature & Male & 183 & 33 \\
\hline 20 & Nautilus pompilius & Immature & Indet. & 105 & 26 \\
\hline 23 & Nautilus pompilius & Immature & Indet. & 112 & 26 \\
\hline 30 & Nautilus pompilius & Immature & Indet. & 147 & 30 \\
\hline 31 & Nautilus pompilius & Immature & Indet. & 136 & 29 \\
\hline 32 & Nautilus pompilius & Immature & Indet. & 136 & 32 \\
\hline 33 & Nautilus pompilius & Immature & Indet. & 135 & 27 \\
\hline 34 & Nautilus pompilius & Immature & Indet. & 144 & 32 \\
\hline 35 & Nautilus pompilius & Immature & Indet. & 124 & 28 \\
\hline 36 & Nautilus pompilius & Immature & Indet. & 157 & 37 \\
\hline 38 & Nautilus pompilius & Mature & Male & 150 & 31 \\
\hline 39 & Nautilus pompilius & Mature & Male & 147 & 32 \\
\hline 40 & Nautilus pompilius & Mature & Male & 151 & 30 \\
\hline 41 & Nautilus pompilius & Mature & Male & 184 & 34 \\
\hline 42 & Nautilus pompilius & Mature & Female & 169 & 33 \\
\hline 43 & Nautilus pompilius & Mature & Male & 155 & 31 \\
\hline 44 & Nautilus pompilius & Mature & Male & 164 & 35 \\
\hline 46 & Nautilus pompilius & Mature & Male & 160 & 31 \\
\hline 48 & Nautilus pompilius & Mature & Male & 165 & 35 \\
\hline 51 & Nautilus pompilius & Mature & Female & 179 & 33 \\
\hline 53 & Nautilus pompilius & Mature & Male & 181 & 36 \\
\hline 54 & Nautilus pompilius & Mature & Male & 164 & 29 \\
\hline 56 & Nautilus pompilius & Mature & Female & 176 & 32 \\
\hline
\end{tabular}




\section{Table 2 (on next page)}

Raw data of measured chamber volumes and widths in Normannites mitis. 


\begin{tabular}{|c|c|c|c|c|}
\hline \multicolumn{5}{|c|}{ Normannites mitis } \\
\hline \multirow{2}{*}{$\begin{array}{l}\text { Specimen } \\
\text { Chamber }\end{array}$} & \multicolumn{2}{|c|}{ Nm. 1} & \multicolumn{2}{|c|}{ Nm. 2} \\
\hline & Volume $\left(\mathrm{mm}^{3}\right)$ & Width (mm) & Volume $\left(\mathrm{mm}^{3}\right)$ & Width (mm) \\
\hline 25 & 0.9 & - & - & - \\
\hline 26 & 1.3 & - & - & - \\
\hline 27 & 2.0 & - & 1.6 & - \\
\hline 28 & 2.1 & 2.6 & 2.5 & - \\
\hline 29 & 2.6 & 2.6 & 3.0 & - \\
\hline 30 & 2.9 & 2.7 & 3.8 & - \\
\hline 31 & 3.4 & 2.6 & 4.8 & - \\
\hline 32 & 4.2 & 3.1 & 5.3 & - \\
\hline 33 & 6.0 & 4.1 & 7.4 & - \\
\hline 34 & 9.6 & 4.1 & 8.8 & - \\
\hline 35 & 8.6 & 4.6 & 11.3 & - \\
\hline 36 & 10.7 & 4.6 & 12.4 & - \\
\hline 37 & 12.9 & 4.6 & 16.2 & 3.9 \\
\hline 38 & 16.0 & 4.6 & 16.8 & 3.9 \\
\hline 39 & 16.2 & 4.7 & 20.4 & 4.8 \\
\hline 40 & 26.1 & 5.5 & 30.8 & 5.8 \\
\hline 41 & 28.9 & 5.8 & 43.1 & 7.2 \\
\hline 42 & 39.2 & 6.5 & 61.0 & 7.7 \\
\hline 43 & 49.7 & 7.4 & 72.4 & 7.7 \\
\hline 44 & 59.1 & 7.9 & 78.6 & 7.7 \\
\hline 45 & 66.7 & 8.4 & 54.0 & 7.2 \\
\hline 46 & 81.4 & 8.9 & 76.3 & 7.2 \\
\hline 47 & 99.4 & 9.4 & 93.1 & 7.9 \\
\hline 48 & 113.3 & 9.8 & 130.4 & 8.6 \\
\hline 49 & 155.1 & 10.3 & 198.6 & 11.0 \\
\hline 50 & 171.8 & 11.3 & 296.0 & 13.2 \\
\hline 51 & 255.9 & 12.5 & 380.5 & 15.1 \\
\hline 52 & 338.7 & 14.6 & 446.4 & 15.1 \\
\hline 53 & 397.6 & 15.1 & 458.6 & 15.1 \\
\hline 54 & 498.5 & 16.6 & 425.7 & 13.9 \\
\hline 55 & 557.4 & 16.6 & 384.6 & 13.4 \\
\hline 56 & 510.2 & 17.5 & 409.1 & 15.1 \\
\hline 57 & 576.1 & 17.5 & 428.5 & 15.4 \\
\hline 58 & 528.4 & 18.0 & 375.1 & 15.9 \\
\hline 59 & 497.3 & 18.0 & 339.3 & 15.4 \\
\hline 60 & 410.5 & 18.0 & - & - \\
\hline
\end{tabular}




\section{Table 3 (on next page)}

Raw data of measured chamber volumes in Nautilus pompilius. 


\begin{tabular}{|c|c|c|c|c|c|c|c|c|c|c|}
\hline \multicolumn{11}{|c|}{ Nautilus pompilius } \\
\hline \multicolumn{11}{|c|}{ Volumes (ml) } \\
\hline Chamber & 7 & 8 & 10 & 11 & 12 & 15 & 16 & 17 & 20 & 23 \\
\hline 1 & 0.0011 & 0.0080 & 0.0082 & 0.0118 & 0.0139 & 0.0088 & 0.0099 & 0.0101 & 0.0153 & 0.0120 \\
\hline 2 & 0.0123 & 0.0331 & 0.0257 & 0.0416 & 0.0384 & 0.0317 & 0.0145 & 0.0307 & 0.0329 & 0.0370 \\
\hline 3 & 0.0468 & 0.1013 & 0.0760 & 0.1056 & 0.1091 & 0.0866 & 0.0424 & 0.0882 & 0.0922 & 0.1440 \\
\hline 4 & 0.1142 & 0.1951 & 0.1539 & 0.1980 & 0.1809 & 0.1571 & 0.1109 & 0.1584 & - & 0.1904 \\
\hline 5 & 0.1837 & 0.2417 & 0.2028 & 0.2214 & 0.2050 & 0.2032 & 0.1859 & 1.9870 & 0.2939 & 0.1658 \\
\hline 6 & 0.2236 & 0.1264 & 0.1397 & 0.1244 & 0.1081 & 0.1327 & 0.2182 & 1.2660 & 0.1387 & - \\
\hline 7 & 0.1287 & 0.1987 & 0.1736 & 0.2603 & 0.1742 & 0.1711 & 0.1610 & 0.1911 & 0.1504 & 0.1875 \\
\hline 8 & 0.1767 & 0.2520 & 0.2027 & 0.2639 & 0.2046 & 0.1654 & 0.2183 & 0.2065 & 0.1695 & 0.2451 \\
\hline 9 & 0.2265 & 0.2800 & 0.2472 & 0.3593 & 0.2370 & 0.2352 & 0.2730 & 0.2418 & 0.2092 & 0.3563 \\
\hline 10 & 0.2619 & 0.3126 & 0.2873 & 0.4043 & 0.3378 & 0.2344 & 0.3047 & 0.2709 & 0.2314 & 0.3615 \\
\hline 11 & 0.3097 & 0.4201 & 0.3461 & 0.4913 & 0.3364 & 0.2671 & 0.3856 & 0.3332 & 0.3010 & 0.2962 \\
\hline 12 & 0.3254 & 0.5510 & 0.4246 & 0.5882 & 0.3992 & 0.3542 & 0.4402 & 0.4326 & 0.4017 & 0.5029 \\
\hline 13 & 0.3419 & 0.6398 & 0.4958 & 0.6988 & 0.4677 & 0.4407 & 0.5293 & 0.4632 & 0.3846 & 0.6454 \\
\hline 14 & 0.4342 & 0.8348 & 0.6386 & 0.9175 & 0.5496 & 0.5297 & 0.6218 & 0.5654 & 0.5069 & 0.7712 \\
\hline 15 & 0.5986 & 0.9723 & 0.7534 & 1.1123 & 0.7096 & 0.5844 & 0.7034 & 0.7108 & 0.5902 & 0.8968 \\
\hline 16 & 0.6954 & 1.1514 & 0.9129 & 1.2902 & 0.8697 & 0.6870 & 0.8370 & 0.8858 & 0.7431 & 1.0808 \\
\hline 17 & 0.7329 & 1.5420 & 0.9722 & 1.5716 & 0.9987 & 0.8377 & 1.1188 & 1.0799 & 0.9711 & 1.3026 \\
\hline 18 & 0.8595 & 1.8436 & 1.2630 & 2.0393 & 1.1376 & 1.0711 & 1.3181 & 1.3902 & 1.1740 & 1.5484 \\
\hline 19 & 1.1690 & 2.4328 & 1.6209 & 2.3768 & 1.4889 & 1.4076 & 1.6280 & 1.7581 & 1.5174 & 1.7800 \\
\hline 20 & 1.3495 & 2.8077 & 1.6611 & 3.1048 & 1.8336 & 1.6886 & 1.8692 & 2.2017 & 1.8071 & 2.4023 \\
\hline 21 & 1.7666 & 3.4284 & 2.2127 & 3.8014 & 2.2195 & 2.2858 & 2.3806 & 2.7137 & 2.2284 & 2.8600 \\
\hline 22 & 2.0429 & 4.7002 & 2.4138 & 5.1772 & 2.8784 & 2.6827 & 3.0621 & 2.9842 & 2.8115 & 3.4343 \\
\hline 23 & 2.6836 & 5.8684 & 3.6654 & 6.4984 & 3.4312 & 3.0022 & 3.8081 & 4.2956 & 3.3740 & 4.4262 \\
\hline 24 & 3.1432 & 7.3975 & 3.9932 & 6.3292 & 4.0784 & 3.9945 & 4.8836 & 5.7708 & 4.3020 & 5.5624 \\
\hline 25 & 3.8981 & 9.2433 & 5.9550 & 10.8780 & 4.8802 & 5.2016 & 6.4403 & 6.5720 & 5.5132 & 6.8422 \\
\hline 26 & 4.7613 & 12.1851 & 7.2257 & 13.0345 & 6.1415 & 6.9912 & 7.7378 & 8.3211 & 6.5154 & 8.3682 \\
\hline 27 & 6.2645 & 14.8837 & 9.1428 & 15.1136 & 7.1537 & 6.9741 & 10.2469 & 9.7510 & - & - \\
\hline 28 & 7.6362 & 18.9061 & 11.6261 & 15.0097 & 9.3969 & 9.9014 & 11.9939 & 12.6750 & - & - \\
\hline 29 & 8.9947 & 23.4334 & 14.3625 & 18.0443 & 11.4332 & 13.0762 & 15.4993 & 15.4005 & - & - \\
\hline 30 & 11.6532 & 21.7685 & 18.6543 & 16.2038 & 13.7770 & 15.9414 & 18.4287 & 17.8146 & - & - \\
\hline 31 & 14.3670 & - & 22.4427 & - & 17.3911 & 21.2605 & 21.4919 & 22.5759 & - & - \\
\hline 32 & 18.7249 & - & 25.6854 & - & 19.8835 & 25.8978 & 26.6814 & 25.5356 & - & - \\
\hline 33 & 22.7825 & - & - & - & 19.3914 & 23.7399 & 21.6118 & 29.6341 & - & - \\
\hline 34 & 28.9011 & - & - & - & - & - & - & - & - & - \\
\hline 35 & 25.0228 & - & - & - & - & - & - & - & - & - \\
\hline
\end{tabular}




\begin{tabular}{|c|c|c|c|c|c|c|c|c|c|c|}
\hline \multicolumn{11}{|c|}{ Nautilus pompilius } \\
\hline \multicolumn{11}{|c|}{ Volumes (ml) } \\
\hline Chamber & 30 & 31 & 32 & 33 & 34 & 35 & 36 & 38 & 39 & 40 \\
\hline 1 & 0.0009 & 0.0081 & 0.0015 & 0.0081 & 0.0076 & 0.0010 & 0.0216 & 0.0098 & 0.0106 & 0.0101 \\
\hline 2 & 0.0093 & 0.0307 & 0.0112 & 0.0138 & 0.0238 & 0.0151 & 0.0566 & 0.0283 & 0.0415 & 0.0413 \\
\hline 3 & 0.0491 & 0.1274 & 0.0372 & 0.0523 & 0.0673 & 0.0441 & 0.1162 & 0.0987 & 0.0610 & 0.1276 \\
\hline 4 & 0.1152 & 0.0900 & 0.1024 & - & - & 0.1044 & 0.1356 & 0.1778 & 0.1955 & 0.2445 \\
\hline 5 & 0.2002 & 0.1677 & 0.1703 & 0.2591 & 0.1836 & 0.1951 & 0.0903 & 0.2302 & 0.2274 & 0.2826 \\
\hline 6 & 0.2263 & 0.2333 & 0.2108 & 0.3325 & 0.0731 & 0.1551 & 0.0677 & 0.1288 & 0.1437 & 0.1377 \\
\hline 7 & 0.1298 & 0.1515 & 0.1059 & 0.1488 & 0.1445 & 0.1211 & 0.0875 & 0.1754 & 0.2137 & 0.1577 \\
\hline 8 & 0.2507 & 0.1968 & 0.1578 & 0.2810 & 0.1506 & 0.2130 & 0.1325 & 0.2319 & 0.2327 & 0.2791 \\
\hline 9 & 0.2457 & 0.2774 & 0.1513 & 0.3327 & 0.1912 & 0.2311 & 0.1384 & 0.2424 & 0.2748 & 0.3210 \\
\hline 10 & 0.3184 & 0.3346 & 0.2389 & 0.3967 & 0.2178 & 0.3198 & 0.1650 & 0.3559 & 0.3628 & 0.3354 \\
\hline 11 & 0.3811 & 0.4392 & 0.2743 & 0.4897 & 0.2891 & 0.3354 & 0.1998 & 0.3528 & 0.3506 & 0.4696 \\
\hline 12 & 0.4743 & 0.4943 & 0.2953 & 0.5830 & 0.2969 & 0.4166 & 0.2167 & 0.4391 & 0.4582 & 0.5265 \\
\hline 13 & 0.5728 & 0.5368 & 0.3519 & 0.6721 & 0.3613 & 0.4578 & 0.2776 & 0.5343 & 0.5336 & 0.6694 \\
\hline 14 & 0.6597 & 0.5660 & 0.4364 & 0.7652 & 0.4548 & 0.4956 & 0.3469 & 0.6659 & 0.5510 & 0.7933 \\
\hline 15 & 0.8527 & 0.6376 & 0.4978 & 0.9763 & 0.5328 & 0.6623 & 0.3984 & 0.8642 & 0.7349 & 0.9906 \\
\hline 16 & 0.9906 & 0.9415 & 0.5625 & 1.1348 & 0.6799 & 0.8069 & 0.4671 & 1.0654 & 0.8903 & 1.1742 \\
\hline 17 & 1.2034 & 1.2099 & 0.6816 & 1.5905 & 0.8066 & 0.9817 & 0.5594 & 1.2510 & 1.1273 & 1.4877 \\
\hline 18 & 1.5362 & 1.4315 & 0.8131 & 1.7629 & 0.9474 & 1.2012 & 0.7268 & 1.5251 & 1.3187 & 1.8743 \\
\hline 19 & 1.7694 & 1.7856 & 0.9522 & 2.2513 & 1.2071 & 1.3979 & 0.8601 & 1.8645 & 1.6630 & 2.3415 \\
\hline 20 & 2.0389 & 1.9788 & 1.1264 & 3.0569 & 1.4379 & 1.8163 & 0.9568 & 2.3037 & 2.1185 & 2.8293 \\
\hline 21 & 2.8880 & 2.6252 & 1.4726 & 3.5649 & 1.7398 & 2.2560 & 1.1435 & 3.0019 & 2.5387 & 3.4876 \\
\hline 22 & 3.3829 & 3.0792 & 1.5172 & 4.5086 & 2.0732 & 2.7278 & 1.3670 & 3.8435 & 3.1226 & 4.1792 \\
\hline 23 & 3.6387 & 4.1283 & 2.0698 & 5.8497 & 2.6354 & 3.5553 & 1.4716 & 5.0250 & 4.3051 & 5.2172 \\
\hline 24 & 5.5978 & 4.8777 & 2.5775 & 7.8330 & 3.0635 & 4.2451 & 1.9052 & 5.9666 & 5.0770 & 6.9681 \\
\hline 25 & 6.6551 & 6.6584 & 2.9776 & 10.0561 & 3.7968 & 5.6042 & 2.1254 & 7.4867 & 6.4071 & 9.1711 \\
\hline 26 & 8.4330 & 8.2790 & 3.7357 & 12.3302 & 4.6313 & 7.0547 & 2.4165 & 9.5045 & 7.9895 & 11.4558 \\
\hline 27 & 10.9828 & 10.7209 & 4.2277 & 16.8159 & 5.7833 & 8.7436 & 3.1417 & 12.3553 & 9.9455 & 14.8504 \\
\hline 28 & 14.0144 & 13.7381 & 5.9748 & - & 6.7042 & 11.2815 & 3.9028 & 15.4332 & 12.1152 & 18.7030 \\
\hline 29 & 17.9875 & 16.9861 & 6.9056 & - & 8.9703 & - & 4.0146 & 19.5149 & 16.8772 & 21.2875 \\
\hline 30 & 22.9906 & - & 8.7325 & - & 10.3012 & - & 5.5218 & 22.3363 & 19.1758 & 20.7897 \\
\hline 31 & - & - & 11.0929 & - & 13.7366 & - & 6.4224 & 21.7169 & 22.8448 & - \\
\hline 32 & - & - & 13.4910 & - & 16.1578 & - & 8.3757 & - & 10.9346 & - \\
\hline 33 & - & - & - & - & - & - & 9.7338 & - & - & - \\
\hline 34 & - & - & - & - & - & - & 13.6863 & - & - & - \\
\hline 35 & - & - & - & - & - & - & 15.1073 & - & - & - \\
\hline
\end{tabular}




\begin{tabular}{|c|c|c|c|c|c|c|c|c|c|c|}
\hline \multicolumn{11}{|c|}{ Nautilus pompilius } \\
\hline \multicolumn{11}{|c|}{ Volumes (ml) } \\
\hline Chamber & 41 & 42 & 43 & 44 & 46 & 48 & 51 & 53 & 54 & 56 \\
\hline 1 & 0.0100 & 0.0054 & 0.0090 & 0.0050 & 0.0265 & 0.0047 & 0.0175 & 0.0061 & 0.0100 & 0.0093 \\
\hline 2 & 0.0292 & 0.0247 & 0.0306 & 0.0186 & 0.0771 & 0.0183 & 0.0470 & 0.0181 & 0.0342 & 0.0315 \\
\hline 3 & 0.0905 & 0.0708 & 0.0881 & 0.0496 & 0.1503 & 0.0468 & 0.1091 & 0.0549 & 0.0913 & 0.0873 \\
\hline 4 & 0.1417 & 0.1532 & 0.1587 & 0.1075 & 0.1971 & 0.0971 & 0.1735 & 0.1069 & 0.1690 & 0.1472 \\
\hline 5 & 0.2076 & 0.2127 & 0.2030 & 0.1600 & 0.1691 & 0.1455 & 0.1890 & 0.1296 & 0.1763 & 0.2053 \\
\hline 6 & 0.1124 & 0.1729 & 0.1402 & 0.1743 & 0.1699 & 0.1296 & 0.1049 & 0.0991 & 0.0946 & 0.2054 \\
\hline 7 & 0.1508 & 0.1493 & 0.1831 & 0.1235 & 0.2227 & 0.0904 & 0.1476 & 0.0782 & 0.2062 & 0.1376 \\
\hline 8 & 0.1697 & 0.2169 & 0.2357 & 0.1846 & 0.2459 & 0.1272 & 0.1975 & 0.1243 & 0.1836 & 0.1697 \\
\hline 9 & 0.2163 & 0.2819 & 0.2991 & 0.1938 & 0.3018 & 0.1317 & 0.2505 & 0.1579 & 0.2436 & 0.2927 \\
\hline 10 & 0.2786 & 0.3644 & 0.3365 & 0.2052 & 0.3498 & 0.1749 & 0.2403 & 0.1804 & 0.3114 & 0.3502 \\
\hline 11 & 0.3207 & 0.4320 & 0.3932 & 0.2967 & 0.4234 & 0.1962 & 0.3590 & 0.2276 & 0.3474 & 0.3969 \\
\hline 12 & 0.4028 & 0.5334 & 0.4842 & 0.3297 & 0.4885 & 0.2544 & 0.3641 & 0.2631 & 0.3622 & 0.4777 \\
\hline 13 & 0.3789 & 0.6502 & 0.5946 & 0.4074 & 0.6444 & 0.2892 & 0.4552 & 0.2786 & 0.4824 & 0.5308 \\
\hline 14 & 0.3697 & 0.8009 & 0.7316 & 0.4628 & 0.7167 & 0.3641 & 0.5052 & 0.3390 & 0.5973 & 0.7307 \\
\hline 15 & 0.4970 & 1.1199 & 0.8541 & 0.5346 & 0.9162 & 0.4755 & 0.6910 & 0.4319 & 0.7167 & 0.9280 \\
\hline 16 & 0.7079 & 1.3768 & 1.0209 & 0.6888 & 1.1237 & 0.5788 & 0.8284 & 0.5339 & 0.9275 & 1.0657 \\
\hline 17 & 0.8187 & 1.6980 & 1.3506 & 0.8180 & 1.4206 & 0.7132 & 0.9799 & 0.6473 & 1.0603 & 1.3458 \\
\hline 18 & 0.9482 & 2.1715 & 1.5373 & 0.9756 & 1.5012 & 0.7694 & 1.2509 & 0.7253 & 1.3217 & 1.4686 \\
\hline 19 & 1.1905 & 2.5023 & 1.9608 & 1.2337 & 2.1029 & 0.9727 & 1.4561 & 1.0164 & 1.5396 & 1.8512 \\
\hline 20 & 1.4391 & 3.1098 & 2.1780 & 1.5515 & 2.4645 & 1.2410 & 1.7334 & 1.0873 & 1.9675 & 2.3222 \\
\hline 21 & 1.7595 & 4.1807 & 2.9540 & 1.9814 & 3.2696 & 1.4992 & 2.1757 & 1.4246 & 2.4795 & 2.8080 \\
\hline 22 & 2.1740 & 5.2048 & 3.5435 & 2.6261 & 3.7837 & 1.9494 & 2.6698 & 1.6820 & 3.0712 & 3.4655 \\
\hline 23 & 2.6913 & 6.7107 & 4.6642 & 2.7189 & 4.6898 & 2.2113 & 3.5267 & 1.9744 & 3.6531 & 4.4481 \\
\hline 24 & 3.3197 & 8.3822 & 5.6355 & 4.1850 & 6.2850 & 2.6959 & 3.8889 & 2.5256 & 4.6271 & 5.2782 \\
\hline 25 & 3.9711 & 9.8258 & 7.2365 & 4.8333 & 7.7151 & 3.3410 & 5.4467 & 3.2210 & 5.7637 & 6.6173 \\
\hline 26 & 5.1796 & 14.0874 & 8.8481 & 6.3843 & 9.6012 & 4.1416 & 7.0138 & 3.7303 & 7.4533 & 8.4093 \\
\hline 27 & 6.3708 & 16.9760 & 10.8568 & 7.8972 & 12.4969 & 5.2332 & 8.5615 & 4.3930 & 9.1647 & 10.4171 \\
\hline 28 & 7.3239 & 20.3430 & 13.3318 & 10.4022 & 16.2270 & 6.3615 & 10.4667 & 4.8603 & 10.4041 & 13.1087 \\
\hline 29 & 9.5327 & 25.8620 & 16.3558 & 13.1177 & 19.5241 & 7.5145 & 13.5815 & 6.7250 & 13.7364 & 15.5874 \\
\hline 30 & 11.9083 & 24.6416 & 18.0790 & 17.3703 & 24.7367 & 9.4214 & 17.3426 & 8.8509 & 18.1738 & 20.3345 \\
\hline 31 & 14.4140 & - & 20.2377 & 20.7735 & 20.2453 & 12.4135 & 20.6539 & 11.0477 & 22.7498 & 22.5689 \\
\hline 32 & 18.5821 & - & - & 27.8035 & - & 15.0377 & 25.8738 & 14.1953 & 24.6066 & 19.6485 \\
\hline 33 & 23.3349 & - & - & 27.8442 & - & 18.3685 & 21.4921 & 17.2212 & 15.7064 & - \\
\hline 34 & 27.2882 & - & - & - & - & 22.6245 & - & 22.1384 & - & - \\
\hline 35 & - & - & - & - & - & 26.4088 & - & 26.0839 & - & - \\
\hline
\end{tabular}




\section{Table 4(on next page)}

Raw data of measured chamber widths of Nautilus pompilius. 


\begin{tabular}{|c|c|c|c|}
\hline \multicolumn{4}{|l|}{ Nautilus pompilius } \\
\hline \multirow[b]{2}{*}{ Chambers } & \multicolumn{3}{|c|}{ Widths (mm) } \\
\hline & Specimen 8 & Specimen 7 & Specimen 53 \\
\hline 6 & - & - & - \\
\hline 7 & - & - & - \\
\hline 8 & - & - & - \\
\hline 9 & - & - & - \\
\hline 10 & - & - & - \\
\hline 11 & 13.8 & - & 13.8 \\
\hline 12 & 14.1 & 11.5 & 14.1 \\
\hline 13 & 14.5 & 12.4 & 14.5 \\
\hline 14 & 15.2 & 13.2 & 15.2 \\
\hline 15 & 16.3 & 14.2 & 16.3 \\
\hline 16 & 16.6 & 15.1 & 16.6 \\
\hline 17 & 17.4 & 16.3 & 17.4 \\
\hline 18 & 18.2 & 17.0 & 18.2 \\
\hline 19 & 19.3 & 17.8 & 19.3 \\
\hline 20 & 20.4 & 19.1 & 20.4 \\
\hline 21 & 21.8 & 20.4 & 21.8 \\
\hline 22 & 22.6 & 21.4 & 22.6 \\
\hline 23 & 24.6 & 22.9 & 24.6 \\
\hline 24 & 26.2 & 24.3 & 26.2 \\
\hline 25 & 30.0 & 26.1 & 30.0 \\
\hline 26 & 30.1 & 27.4 & 30.1 \\
\hline 27 & 32.3 & 29.2 & 32.3 \\
\hline 28 & 34.0 & 31.0 & 34.0 \\
\hline 29 & 36.2 & 33.1 & 36.2 \\
\hline 30 & 39.7 & 36.1 & 39.7 \\
\hline 31 & 42.4 & 38.9 & 42.4 \\
\hline 32 & 45.2 & 41.7 & 45.2 \\
\hline 33 & 48.3 & 44.7 & 48.3 \\
\hline 34 & 52.8 & 47.9 & 52.8 \\
\hline 35 & 55.6 & 51.5 & 55.6 \\
\hline 36 & - & 54.5 & - \\
\hline
\end{tabular}




\section{Table 5 (on next page)}

Results of statistical tests (analyses of the residual sum of squares) comparing linear regressions of males and female.

$\mathrm{N}$, number of samples; RSS; residual sum of squares; DF, degree of freedom; ns, not significant; s; significant. 


\begin{tabular}{|c|c|c|c|c|c|c|c|c|}
\hline Comparison & $\mathrm{N}$ (male) & $\begin{array}{c}\mathrm{N} \\
\text { (female) }\end{array}$ & RSS (male) & RSS (female) & $\mathrm{DF}$ (male) & DF (female) & $\mathrm{t}$ & Siginificance \\
\hline $\begin{array}{l}\text { Chamber number vs. chamber volume } \\
\text { (between the 1st and 5th chambers)) }\end{array}$ & 60 & 45 & 59.9 & 4601 & 58 & 43 & 0.005 & ns $(\mathrm{P}>0.5)$ \\
\hline $\begin{array}{l}\text { Chamber number vs. chamber volume } \\
\text { (from the 6th chamber) }\end{array}$ & 332 & 243 & 108.3 & 104.0 & 330 & 240 & 16.8 & $\mathrm{~s}(\mathrm{P}<0.05)$ \\
\hline Maximum diameter vs. number of chambers & 12 & 9 & 46.5 & 14.6 & 10 & 7 & 1.9 & $\mathrm{~s}(\mathrm{P}<0.1)$ \\
\hline Maximum diameter vs. total volume of phragmocone & 12 & 9 & 927.6 & 721.0 & 10 & 7 & 2.2 & $\mathrm{~s}(\mathrm{P}<0.1)$ \\
\hline
\end{tabular}




\section{Table 6 (on next page)}

Results of a statistical test (an analysis of the residual sum of squares) comparing nonlinear regressions of males and females.

RSS; residual sum of squares; DF, degree of freedom; ns, not significant; s; significant. 
Comparison

RSS (total)

RSS (male)

RSS (female)

DF (male)

DF (female)

1040.4

332

243

F Siginificance

(from the 6th chamber)

2775.3

1670.0

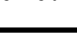

4.55

$\mathrm{s}(\mathrm{P}<0.1)$

1 